\title{
AN INVESTIGATION OF THE EFFECTS OF NEW BYPASS ROADS ON BUILD FORM IN SMALL TOWNS IN SRI LANKA
}

\author{
S Sewwandi ${ }^{a}$ and A Jayasinghe ${ }^{b *}$ \\ a Research Assistant, Urban Simulation Lab, Department of Town \& Country \\ Planning, University of Moratuwa, Moratuwa, Sri Lanka. \\ b Senior Lecturer, Department of Town \& Country Planning, University of \\ Moratuwa, Moratuwa, Sri Lanka. \\ * Corresponding author E-mail address: amilabj@uom.lk
}

\begin{abstract}
This study explores the effects of bypass roads on the build form of small towns in Sri Lanka. The small towns analysed are Avissawella, Mawanella, Balangoda and Piliyandala.

The results of the study indicate three impact scenarios: i) the bypass road has more accessibility than the existing main road and new land uses, and high-density areas emerge along the by-pass road, making this the town centre; ii) both bypass road and the existing main road show similar levels of accessibility and attractiveness. iii) accessibility of the existing main road remains higher than the bypass road and very new developments are attracted towards the bypass road - thus the existing main road remains the main centre of the town. The results confirm that spatial and economic forces are closely interrelated as indicated in the theory of the natural movement economic process. However, the study found that the above forces are constrained by natural barriers.

These findings are useful for transport engineers when making new strategies to implement bypass roads and to urban planners to develop local development plans after constructing bypass roads.
\end{abstract}

Keywords: Bypass road, Accessibility, Network centrality, Land use changes, Transport planning 


\section{INTRODUCTION}

Economic and urban developments that grow along major arterial roads are the most common spatial characteristics of small and medium sized towns in Sri Lanka [1]. These create a number of problems such as traffic congestion, safety, noise and air pollution etc [2]. Bypass roads have been introduced to overcome these problems. A bypass road is one that avoids an existing high-density built-up area in a city or town, allowing traffic to flow without interference from local traffic in that area: typically, a city- or town centre. A bypass road also replaces the main transport route outside the town or city. The main objectives of bypass roads are to reduce the traffic congestion of the town centre while improving mobility. The bypass construction usually focuses on redirecting vehicles that travel through the existing high-density built-up areas in cities and towns with no intention of engaging in activities such as shopping. This improves overall travel time and mobility, reducing the adverse impacts of traffic congestion. A bypass road can dramatically change land use and growth patterns in small and medium sized towns. It also has the potential to positively or adversely affect the physical and socio-economic setting of those towns [3]. Therefore, transport and urban planning agencies have the responsibility to identify and demonstrate the potential physical and socio-economic impacts before constructing a new bypass road development project. However, a limited number of studies have been carried out in Sri Lanka to study the impact of bypass roads in towns when the main transport route is replaced by another thoroughfare outside the town. In this context, the present study explores the effects of a bypass road on build form of a town and investigates the changes in land use and building density that accompany changes in accessibility. This study also analyses the before and after situations for bypass roads in four small towns in Sri Lanka: namely, Avissawella, Mawanella, Balangoda and Piliyandala.

There are few research studies which have investigated the impact of a newly introduced bypass road on land use and build densities in cities. For example, in 1995 Falleth et. al [4] conducted a research on how new bypass roads affect the land use of towns in Norway. The authors observed that new economic activities shifted towards the junctions where bypass roads touch existing settlements. Van Nes et. al [5] investigated how inner and outer ring roads affect the location pattern of shops. The results of that study show "shops located themselves along the highest integrated [highest accessible] street". Van Ness and Stolk [6] analysed two road proposals for the Dutch city Leiden. Both cases show that new roads integration [accessibility] values surpass the existing city centres integration [accessibility] values after constructing bypass roads and new investments begin to emerge in these areas. Sander, et. al [2] and Jayasinghe et. al [7] claim that integration [accessibility] is the major factor affecting new attractions, investments and urbanization. Results of those studies indicate that a new bypass road changes the integration value [accessibility] 
of the road network and will affect the location pattern of shops [land use and built density]. The results of these studies are consistent with the theory of the movement economy. The theory, "built on the notion of natural movement, proposes that evolving space organization in settlements first generates the distribution pattern of busier and quieter movement pattern flows, which then influence land use choices, and these in turn generate multiplier effects on movement with further feedback on land use choices and the local grid as it adapts itself to more intensive development" [8]. Munasinghe [1] has demonstrated that most of the urban areas in Sri Lanka have grown spontaneously as the result of a self-organizing process: this relates to the theory of the natural movement process. He notes that when a new road is constructed, it creates land-use changes and activities due to new levels of accessibility. However, he argues that the process of self-organising is disturbed due to growing social, economic and environmental issues. Perera [9] has demonstrated that powerful companies, institutions, and individuals also create a physical and political space based on income and social and political power. These theories and ideologies argue that the movement economy can be disturbed due to the above factors. Against this background, this study explores the effects of bypass roads on build form of the town and the factors that influence such changes.

\section{METHOD OF STUDY}

\subsection{Case Study Areas}

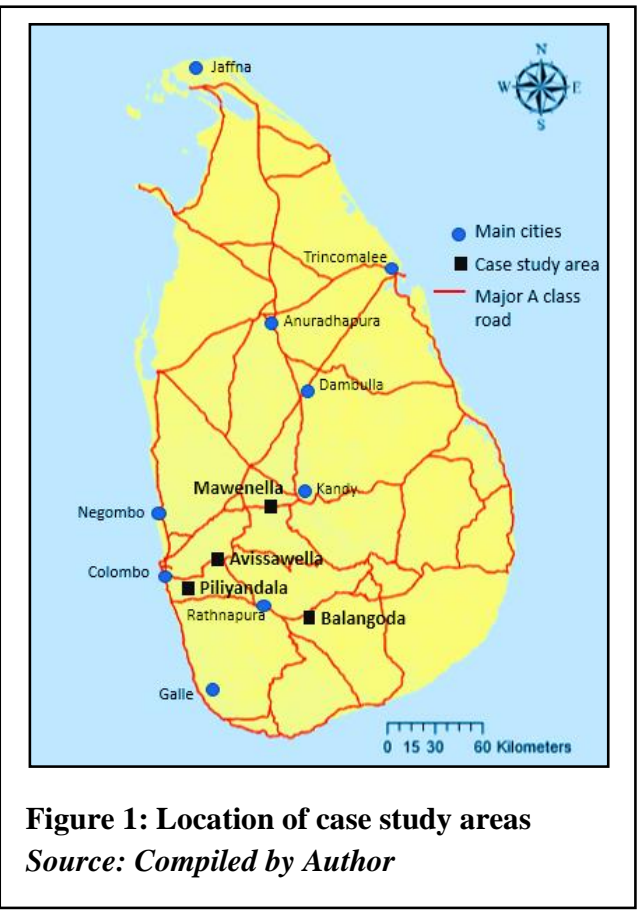

The selected case study areas are Avissawella, Mawanella, Balangoda and Piliyandala. Of these, Avissawella and Piliyandala are located in the Western Province and the Mawanella and Balangoda bypass roads are located in the Sabaragamuwa Province of Sri Lanka.

Table 1 below provides a brief description of these areas. secondary data and the year that the bypass road has been implemented are key factors considered in selecting these case study areas. The data collected is related to road network, land use and buildings, considering different time periods ie, before and after the bypass road implementation. 
Table 1: Selected four case study area and its characteristics.

\begin{tabular}{|c|c|c|c|c|}
\hline $\begin{array}{c}\text { Case study } \\
\text { area }\end{array}$ & $\begin{array}{c}\text { Extent } \\
\mathbf{K m}^{\mathbf{2}}\end{array}$ & $\begin{array}{c}\text { Population } \\
\mathbf{( 2 0 1 2 )}\end{array}$ & $\begin{array}{c}\text { Year of bypass road } \\
\text { implemented }\end{array}$ & $\begin{array}{c}\text { Use before bypass } \\
\text { road implemented }\end{array}$ \\
\hline Avissawella & 19.7 & 30,308 & 1991 & Railway line \\
\hline Mawanella & 5.43 & 8,993 & 2000 & Vegetation cover \\
\hline Balangoda & 26.5 & 16,510 & 2006 & Vegetation cover \\
\hline Piliyandala & 35.28 & 185,22 & 2014 & Paddy land \\
\hline
\end{tabular}

Source: Compiled by author

\subsection{Data}

Table -A1 and Table-A2 appended provide brief description about the data used in this analysis. (Refer Appendices).

\subsection{Data Preparation and Analysis}

The primary and secondary data were entered and stored in a Geographic Information System (GIS). Then, the study analysed the temporal changes utilising spatial analysis tools in the GIS environment; and utilised three parameters of land use intensity, building density and accessibility to capture temporal changes in selected case town areas. The following section explains three parameters in detail.

\subsubsection{Land-use intensity}

The study utilised the category level land-use intensity analysis to capture temporal changes. Category level land-use intensity analysis captures the "intensity change of each land category within a particular time interval" [10]. The study utilised the following equations (Eq $1 \& \mathrm{Eq} 2)$ to compute land use grain intensity (Gtj) and annual loss intensity (Lti). Figure -A1 under appendices illustrates the steps that follow to compute temporal changes in land use intensity. (Refer appendices)

$$
\begin{aligned}
\mathrm{G}_{\mathrm{tj}} & =\frac{\left[\left(\sum_{\mathrm{i}=1}^{\mathrm{j}} \mathrm{C}_{\mathrm{tij}}\right)-\mathrm{C}_{\mathrm{tij}}\right] /\left(\mathbf{Y}_{\mathrm{t}+1}-\mathbf{Y}_{\mathrm{t}}\right)}{\sum_{\mathrm{i}=1}^{\mathrm{j}} \mathrm{C}_{\mathrm{tij}}} * 100 \% \ldots \ldots \ldots \ldots \ldots \ldots \ldots \ldots \ldots \\
L_{t i} & =\frac{\left[\left(\sum_{\mathrm{j}=1}^{\mathrm{j}} \mathrm{C}_{\mathrm{tij}}\right)-\mathrm{C}_{\mathrm{tii}}\right] /\left(\mathrm{Y}_{\mathrm{t}+1}-\mathrm{Y}_{\mathrm{t}}\right)}{\sum_{\mathrm{j}=1}^{\mathrm{j}} \mathrm{C}_{\mathrm{tij}}} * 100 \% \ldots \ldots \ldots
\end{aligned}
$$

Where,

$\mathrm{i}=$ index for a category at the interval's initial time point

$\mathrm{j}=$ index for a category at the interval's final time point

$\mathrm{t}=$ index for a time point, 
$C_{t i j}=$ numbers that transit from category $i$ at time $Y_{t}$ to category $j$ at time $Y_{t+1}$

$\mathrm{G}_{\mathrm{t} j}=$ annual intensity of gross gain of category $\mathrm{j}$ for time interval

$\mathrm{Lti}=$ annual intensity of gross loss of category i for time interval

\subsubsection{Building density}

There are several methods to measure building density such as the Floor Area Ratio (FAR), Plot coverage and Building block coverage [11]. Of these, Floor Area Ratio (FAR) and plot coverage methods were used to compute building density. The study utilised space matrix to capture temporal changes in building density. Space metrics explains density as a multi-variable phenomenon and relates density to build mass (urban form). The Space Matrix method helped to clarify the confusion in terms used by urban planners who work with urban density. The most important contribution of the space matrix method, apart from a clear definition of density, is that it relates density to urban shape and other events [12]. Figure-A2 under appendices illustrates the steps followed to compute temporal changes in building density. (Refer appendices)

$$
\begin{aligned}
& F A R=\frac{\text { Floor area }(\text { building footage })}{\text { Lot area(land area })} * 100 \ldots \ldots \ldots \text { (3) } \\
& \text { Plot coverage }=\frac{\text { Building area }}{\text { Site area }} * 100 \ldots \ldots \ldots \ldots \text { (4) }
\end{aligned}
$$

\subsubsection{Accessibility}

In this step, accessibility was analysed using the network centrality assessment (NCA) [13] approach. The study computes the level of accessibility based on closeness and betweenness centrality parameters. Closeness centrality (CC) explains, "the notion of accessibility of a road segment measures how close the road segment is to all others road segments in the network along the shortest path" [14], [15], [16]. Betweenness captures (BC) "a special property in a particular road segment that does not act as either origin or destination but as a pass-by location... which is the number of shortest paths between two nodes that contain the given node" [14], [15]. CC captures the volume of trip attraction to a given road segment due to accessibility and $\mathrm{BC}$ captures the volume of pass-by trips which bypass the given road segment due to the intermediacy [13]. "BC performs a key role in explaining traffic volumes in locations where there are more pass-by trips such as regional roads that connect residential townships to a major city. CC is the key to explain the variations in traffic volumes at trip-generation locations such as shopping districts [13].The study utilized the Spatial Design Network Analysis (SDNA) tool [17] in Geography Information System (GIS) environment to compute BC and CC. The tool requires a 'network graph' file as the input and 'analysis option' to compute BC and CC [18]. This study utilizes the 'road-segments' graph method [19], [20] and the 'angular analysis' option 
to compute the shortest-path. Furthermore, the study considered two radiuses of a node to the network influence area as $500 \mathrm{~m}$ and $10 \mathrm{~km}$ to capture the attraction of pedestrian movement and the attraction of vehicle movement respectively. Figure-A3 under appendices illustrates the steps that follow to compute temporal changes in BC and CC. (Refer appendices)

$$
\begin{aligned}
& C C^{r}(\mathrm{i})=\frac{1}{\sum_{\mathrm{j} \neq \mathrm{i}} \mathrm{d}_{i j}} \ldots \ldots \ldots \ldots \ldots \ldots(5) \\
& B C^{r}(\mathrm{i})=\sum_{\mathrm{j} \neq \mathrm{i} \neq \mathrm{k}} \frac{\mathrm{p}_{j k}(i)}{\mathrm{p}_{j k}} \ldots \ldots \ldots \ldots(6)
\end{aligned}
$$

Where:

$C C^{r}(\mathrm{i})=$ Closeness centrality of road segment ' $i$ ' within the search radius $r$,

$B C^{r}(\mathrm{i})=$ Betweenness centrality of road segment ' $i$ ' within the search radius $r$, $\mathrm{N}=$ Total number of road segments [i.e. nodes in dual graph] in the network, $\mathrm{d}_{i j}=$ Distance between road segments ' $i$ ' and ' $j$ ' along the shortest path, $\mathrm{p}_{j k}(i)=$ Number of geodesics [shortest paths] between road segments ' $j$ ' and ' $k$ 'that passing through road segment ' $i$ ',

$p_{j k}=$ Number of geodesics [shortest paths] between segments ' $\mathrm{j}$ ' and ' $\mathrm{k}$ '

\section{ANALYSIS AND FINDINGS}

The study analysed the temporal changes in selected case study areas utilizing three parameters as land use intensity, building density and accessibility to capture the impact of bypass roads. Accordingly, the following sections explain the key findings of each case study area.

\subsubsection{Avissawella}

Avissawella is a small town (population $=30,308$ ) situated on the A4 route from Colombo to Rathnapura. The bypass road in Avissawella was constructed in the year 1991. Figures 2,3 and 4 illustrate the variations of accessibility in the road network of Avissawella town over four different time periods ie., 1989, 1992, 2007, 2019. The level of accessibility is computed based on closeness (CC) and betweenness (BC) centrality parameters. BC-n values of the road network has been dramatically changing over the last two decades after the construction of the bypass road. As depicted in Figure 2, the prominence of the main road has been reduced while the bypass road has attracted higher BC values. It indicates that the bypass road has more potential to capture pass by trips than the existing road. As depicted in Figure 3, CC-500m values have gradually increased in both roads over the last two decades. 

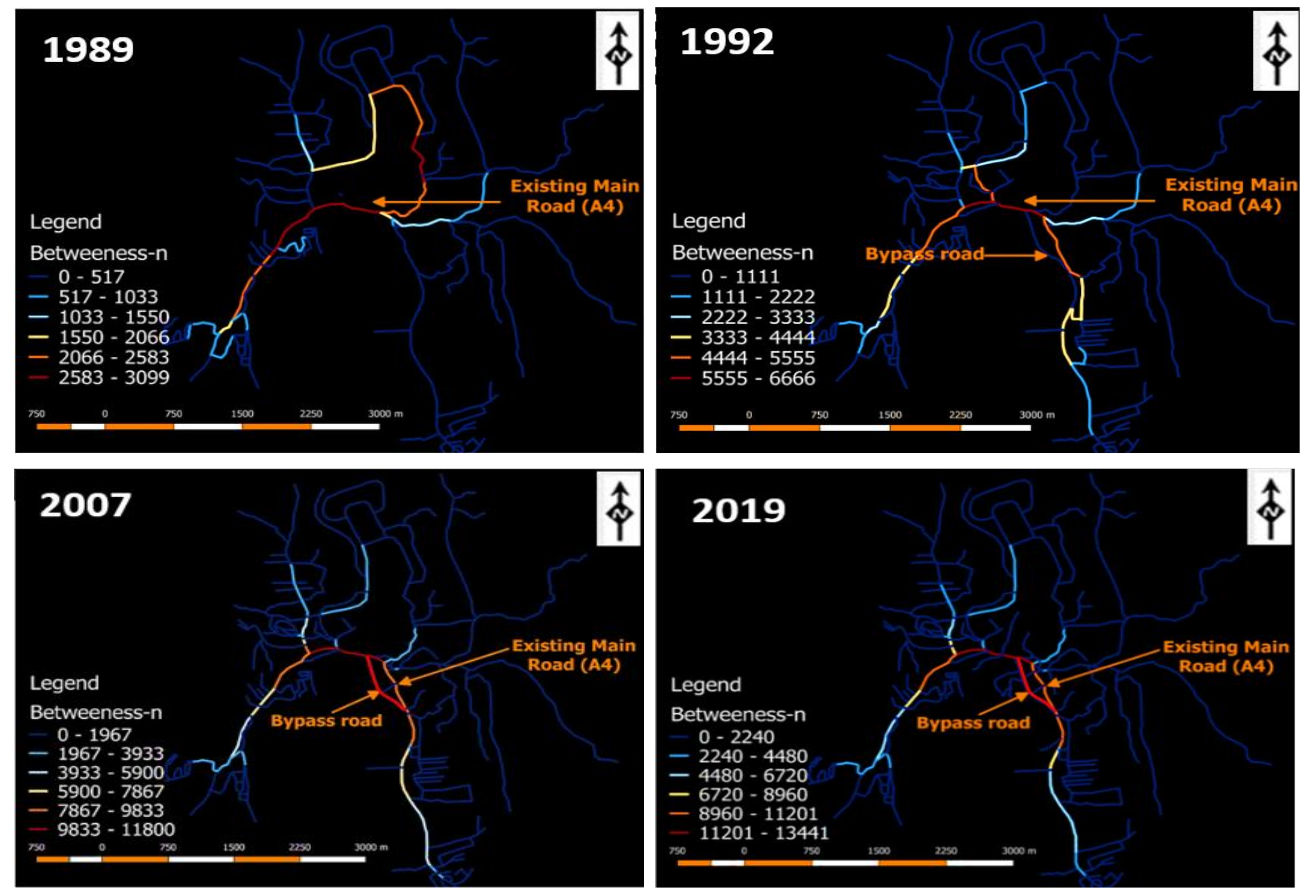

Figure: 2: Variation of betweenness values in road network of Avissawella town before and after bypass road construction.
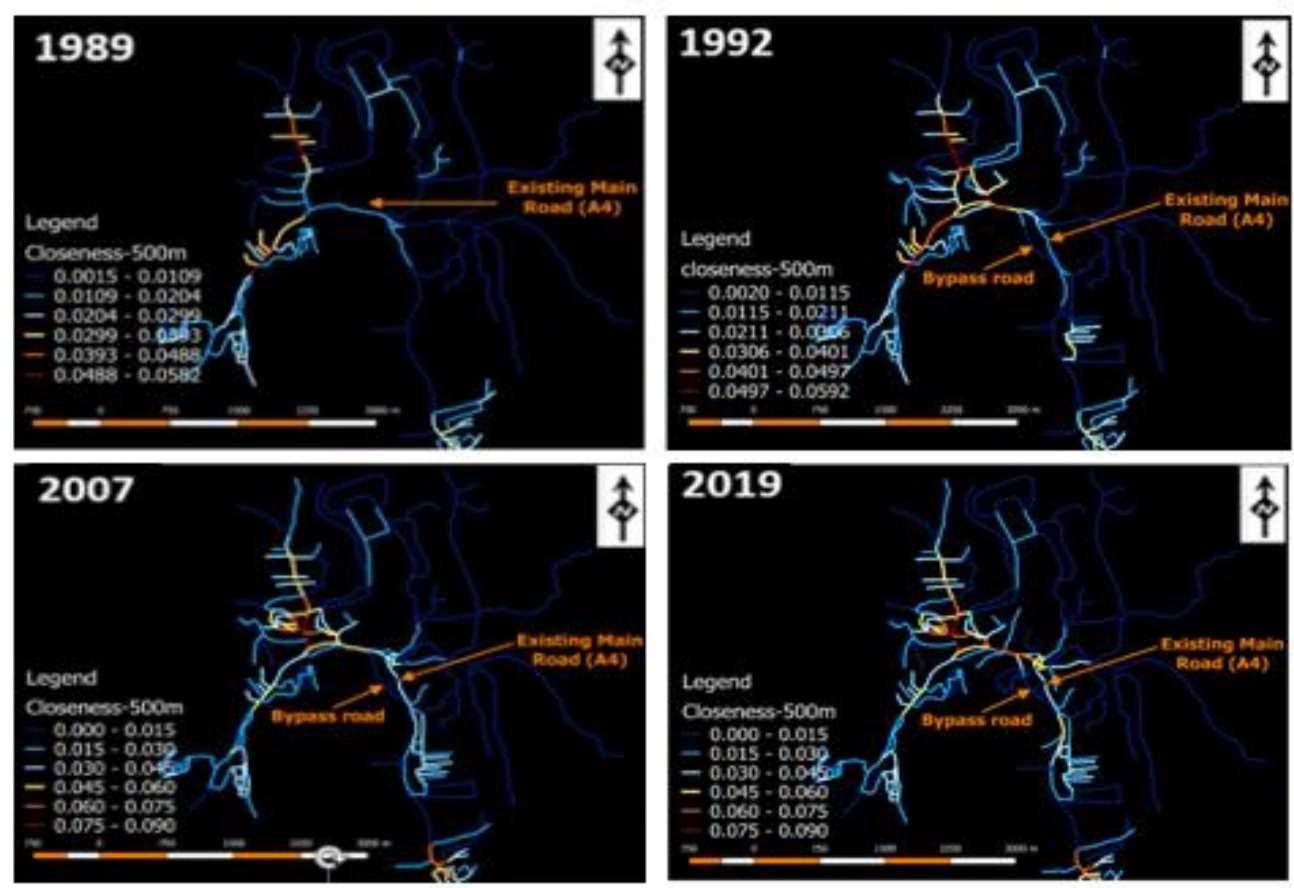

Figure 3: Variation of Closeness-500m values in road network of Avissawella town before and after bypass road construction. 
However, the existing road records a higher CC-500m value compared to the bypass road. Furthermore, there are very few connections between the bypass road and the existing road. It indicates that the bypass road has less potential to attract pedestrian movement, compared to the existing road.

As depicted in Figure 4, CC-n values have been very much similar in both roads over last two decades. It indicates that both roads have a similar level of potential to attract vehicle movements. (In the reference map series, changes in value of $\mathrm{BC}$ and $\mathrm{CC}$ are visible through the six colour ranges in the maps. The highest $\mathrm{BC}$ and $\mathrm{CC}$ values are shown in red and the lowest values are shown in blue. Accordingly, the use of colour range (Red to Blue) or values mention in legend help to identify BC and $\mathrm{CC}$ changes along the bypass and the existing road.)
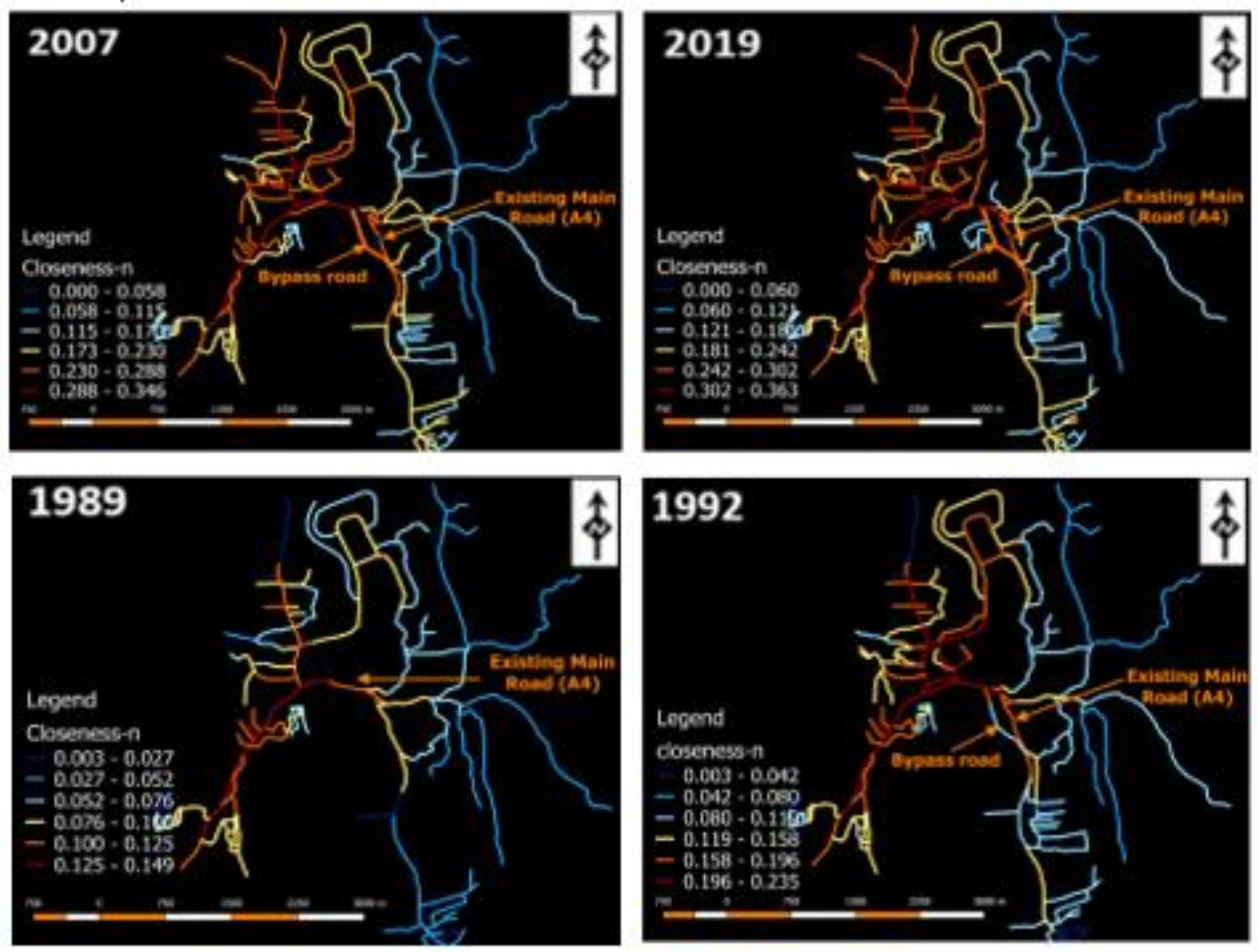

Figure 4: Variation of Closeness-n values in road network of Avissawella town before and after bypass road construction.

Figure 5 depicts the changes in building density in Avissawella from 1989 to 2019 with floor area ratio maps. With the construction of the new bypass road, new buildings have gradually appeared along new bypass road. However, building density along the existing main road $(\mathrm{FAR}=2)$ remain higher than the building density along the bypass road $(\mathrm{FAR}=1)$. 

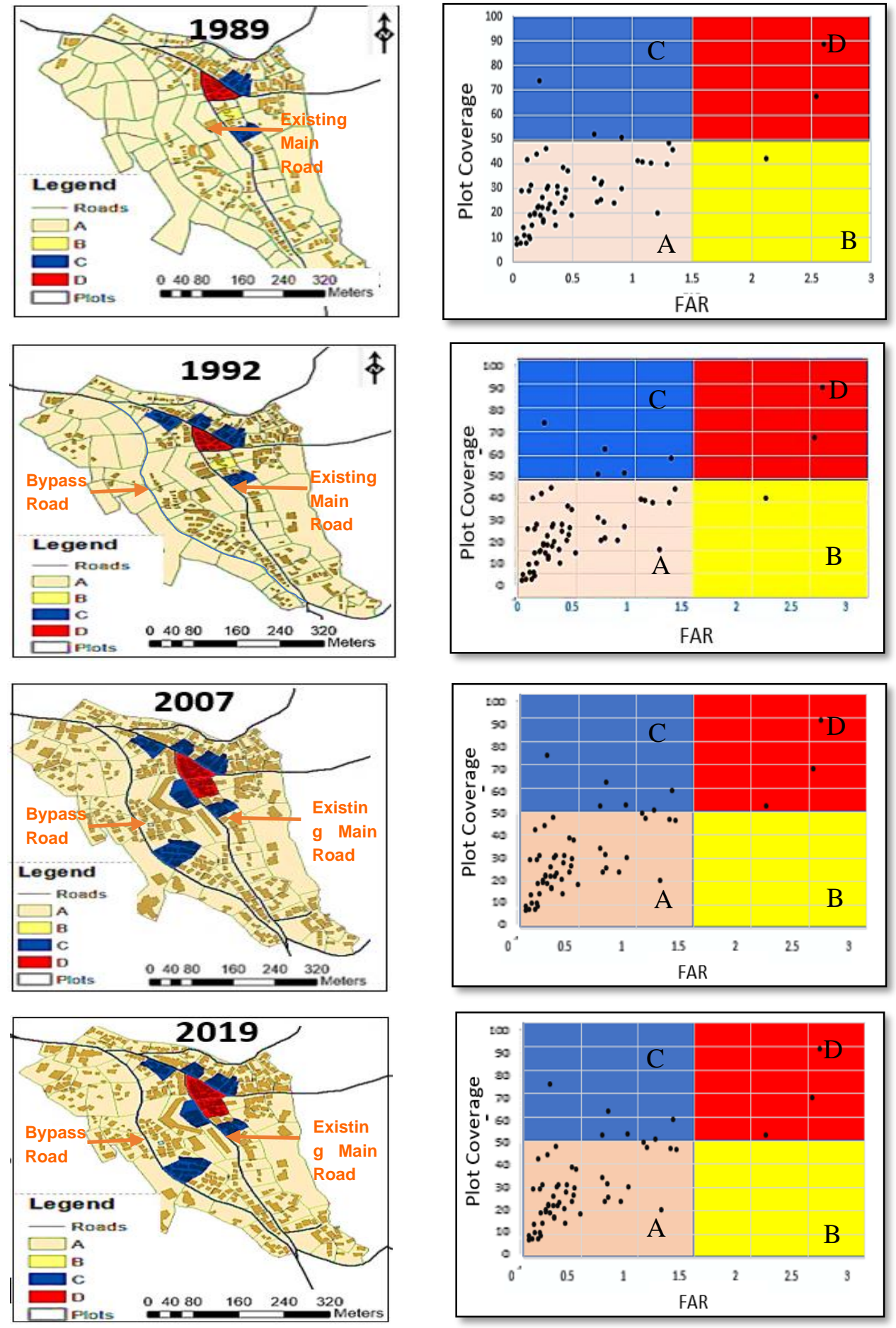

Figure 5: Variation of FAR values in building density of Avissawella town before and after bypass road construction 

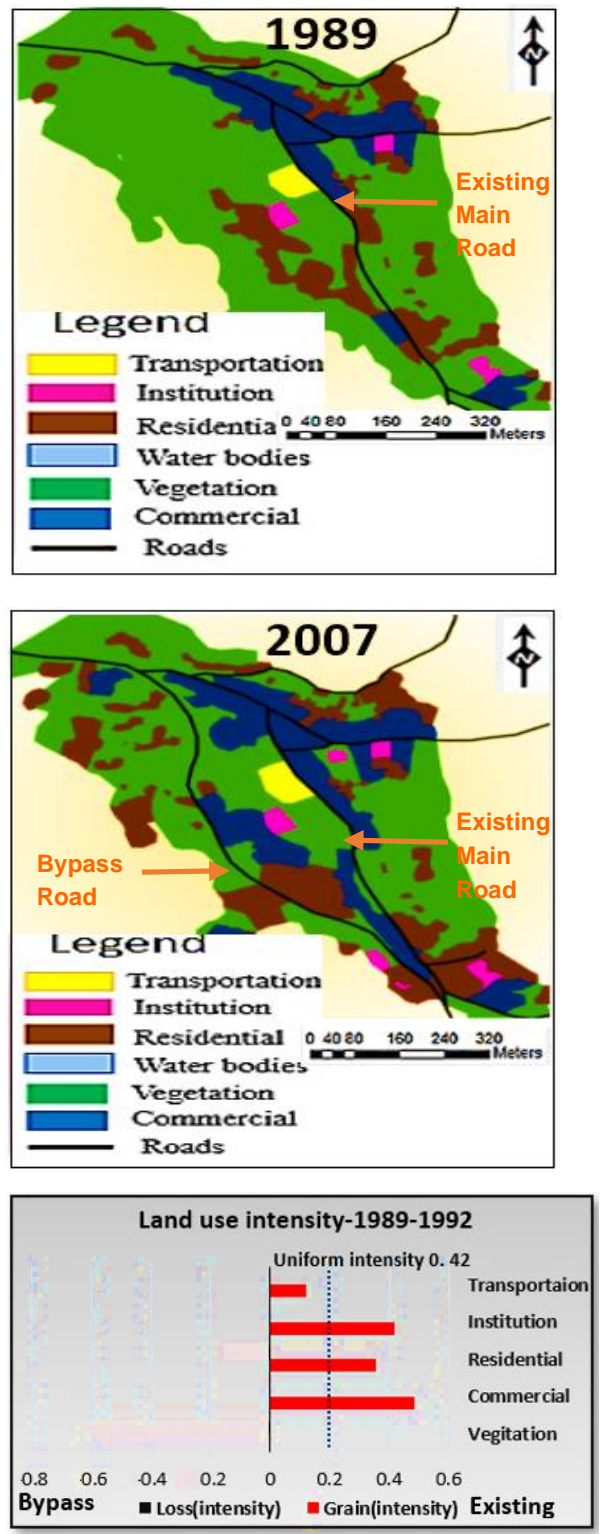
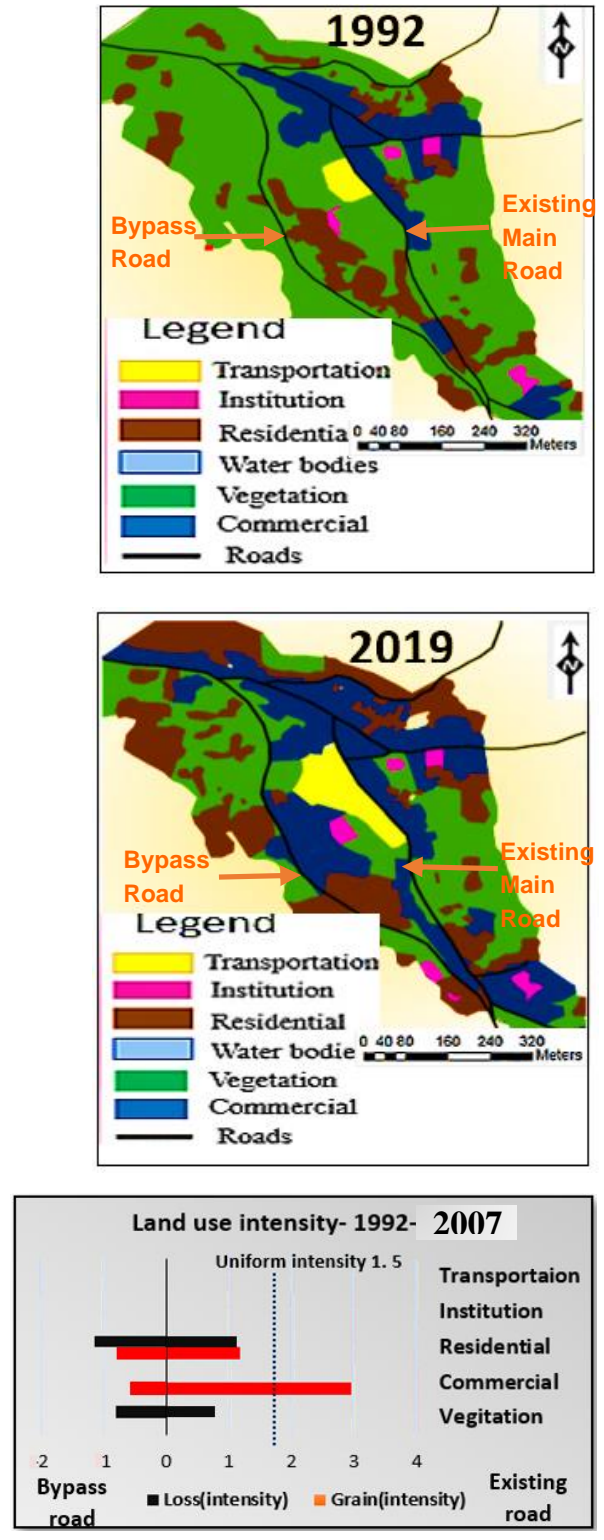

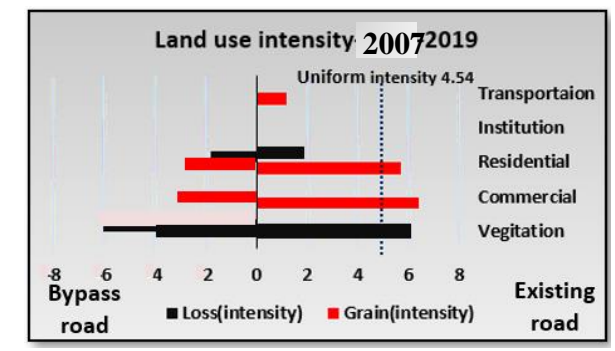

Figure 6: Variation of land use intensity values in land use of Avissawella town before and after bypass road construction. 
Figure 6 above depicts the results of the land use intensity analysis. As per the results, there was significant growth in commercial land uses along the existing road during the period of 1989 to 1992 (after bypass roads). Further, many residential land uses have been converted into commercial sectors along the existing road. In the early stages (1992-2007) the bypass road was able to attract residential land uses and gradually the bypass road was also able to attract commercial land use during the period of $2007-2019$.

Table 2 : Summary of changes in Avissawella town area.

\begin{tabular}{|c|c|c|c|c|c|}
\hline \multirow[t]{2}{*}{ Parameters } & \multirow{2}{*}{$\begin{array}{c}\text { Existing/ } \\
\text { Bypass }\end{array}$} & \multicolumn{4}{|c|}{ Years } \\
\hline & & 1989 & 1992 & 2007 & 2019 \\
\hline \multirow[t]{2}{*}{ Building density } & Existing & 1.2 & 1.2 & 1.2 & 2 \\
\hline & Bypass & - & 0.42 & 1 & 1 \\
\hline \multirow[t]{2}{*}{ Betweenness } & Existing & 1699 & 20187 & 3246 & 3495 \\
\hline & Bypass & - & 244 & 7296.5 & 7935 \\
\hline \multirow[t]{2}{*}{ Closeness_500m } & Existing & 0.0182 & 0.0507 & 0.025 & 0.091 \\
\hline & Bypass & - & 0.005 & 0.0195 & 0.0485 \\
\hline \multirow[t]{2}{*}{ Closeness } & Existing & 0.107 & 0.194 & 0.314 & 0.35 \\
\hline & Bypass & - & 0.1295 & 0.359 & 0.3686 \\
\hline \multirow[t]{2}{*}{ Land use type } & Existing & 2 & 1 & 1 & 1 \\
\hline & Bypass & - & 3 & 3 & 2 \\
\hline \multirow[t]{2}{*}{ Land use mix } & Existing & - & $\begin{array}{l}1=(+0.5) \\
2=(+0.4) \\
3=(0.15) \\
4=(+0.4) \\
5=(+0.05)\end{array}$ & $\begin{array}{c}1=(+3) \\
2=(+1),(-0.9) \\
3=(-0.85)\end{array}$ & $\begin{array}{c}1=(+6.5) \\
2=(+6),(-2) \\
3=(-6.2) \\
5=(+1)\end{array}$ \\
\hline & Bypass & - & - & $\begin{aligned} & 1=(+0.5) \\
2= & (+0.7),(-1.3) \\
& 3=(-1.8)\end{aligned}$ & $\begin{array}{c}1=(+3) \\
2=(+3.5),(-2) \\
3=(-4)\end{array}$ \\
\hline
\end{tabular}

$* 1=$ Commercial, $2=$ Residential, $3=$ Vegetation, 4=Institution, 5= Transportation $*_{+}=$Grain intensity, - = Loss intensity

The changes in the Avissawella case study area due to the bypass road can be summarised as follows: With higher $\mathrm{BC}$ values, the bypass road was able to attract more pass-by trips than the existing road. The analysis of result of the previous 
section indicates that the accessibility (CC values) had increased in both roads. Accordingly, land use along both roads have gradually changed. However, the bypass road was unable to attract commercial land uses and high density, when compared to the existing road. Furthermore, the existing main road remains as the centre of the town. Avissawella town centre is located below $35 \mathrm{~m}$ elevation MSL, but the bypass road elevation is more than $50 \mathrm{~m}$. Besides, there is a mountain along the bypass road (refer Figure 7), that restricts the space to grow and acts as a barrier to attract new activities along the bypass road. The case study results indicate that the natural movement of economic process is disturbed due to lack of space. Table 3 show existing traffic flow data on both existing and bypass roads and it confirms that the bypass road has a high level of service relative to the existing road.

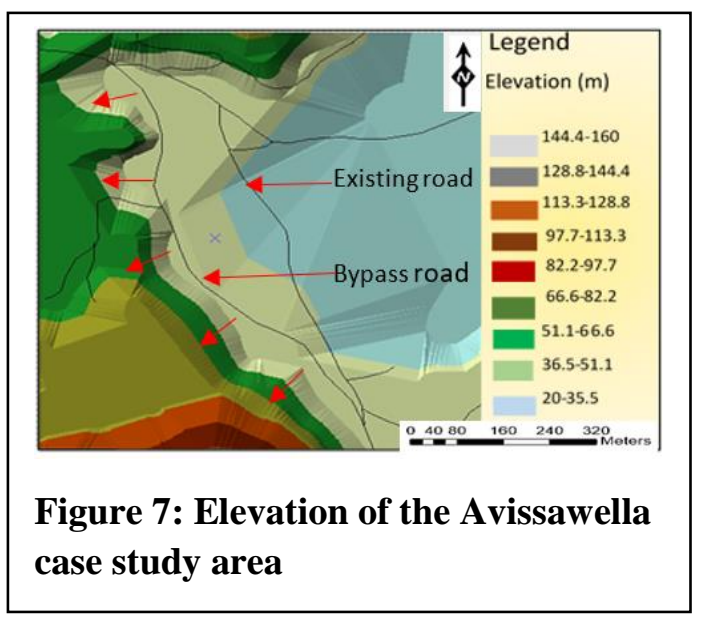

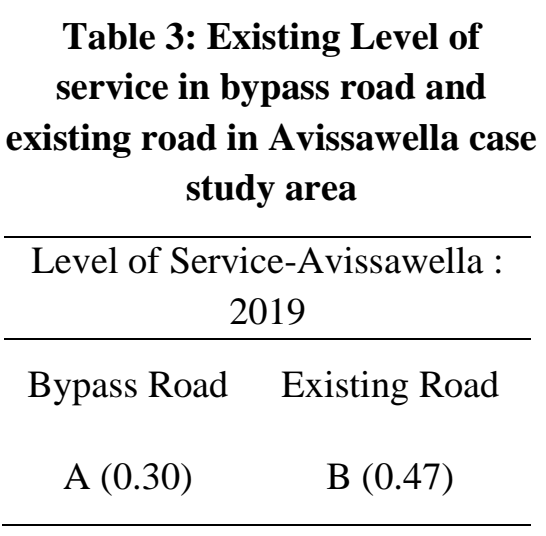

Source: Compiled by author

\subsubsection{Mawanella}

Mawanella is a small town (population $=111,727$ ) situated on the A1 route from Colombo to Kandy. The bypass road in Mawanella was constructed in year 2000. Figures 8,9 and 10 illustrate the variations of accessibility in the road network of Mawanella town over three different time periods (1999, 2010, 2019). BC-n values of the road network has been dramatically changing over the last two decades after the construction of the bypass road. As depicted in Figure 8, the prominence of the main road has been reduced while the bypass road has attracted higher BC values. This indicates that the bypass road has more potential to capture pass by trips than the existing road. As depicted in Figure 9, CC-500m values have gradually increased in both roads over the last two decades. However, the bypass road records a higher CC-500m value when compared with the existing road. Furthermore, there are good connections between the bypass road and the existing road. This indicates that the bypass road has a high potential of attracting pedestrian movement. 


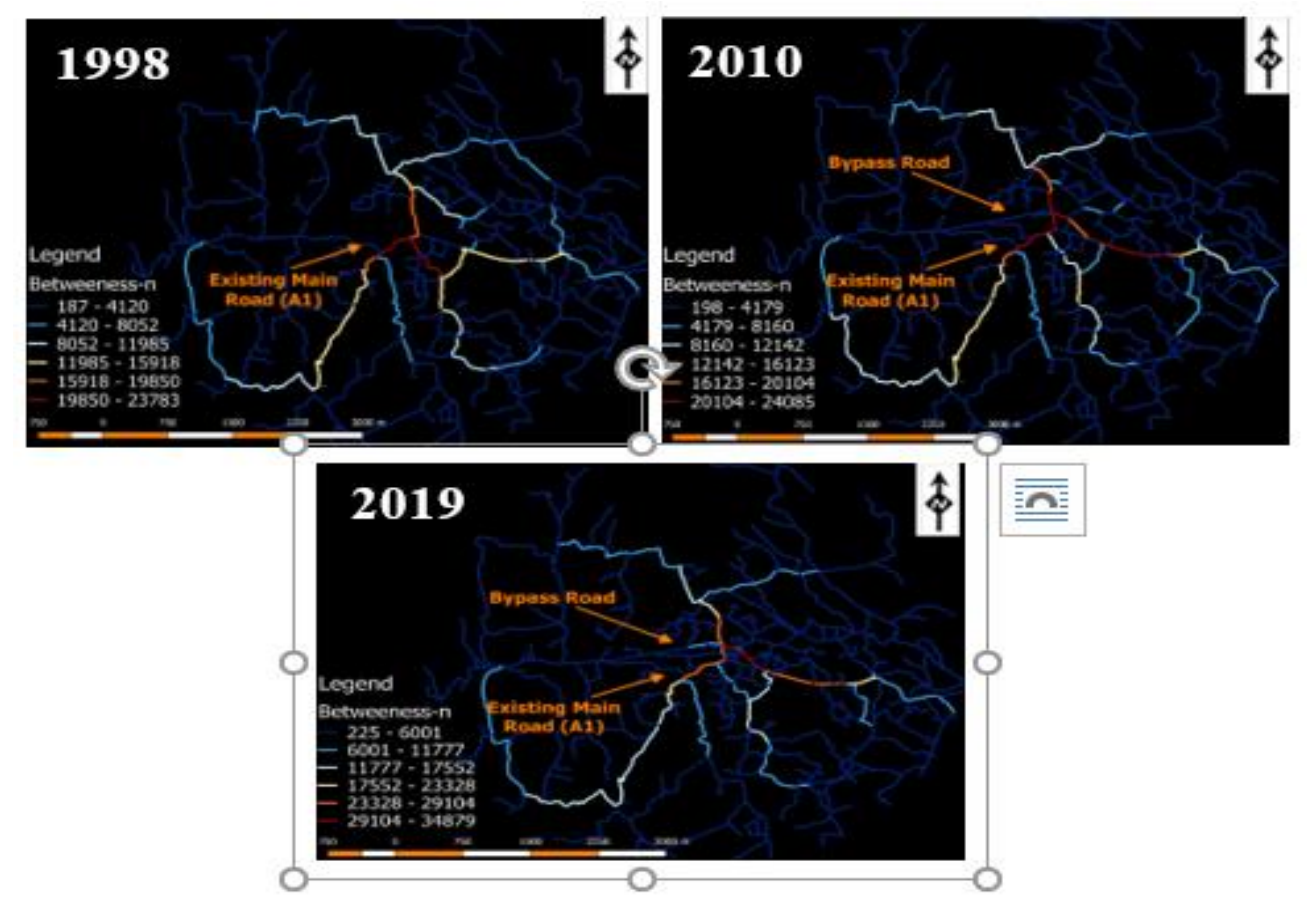

Figure 8: Variation of betweenness values in road network of Mawanella town before and after bypass road construction

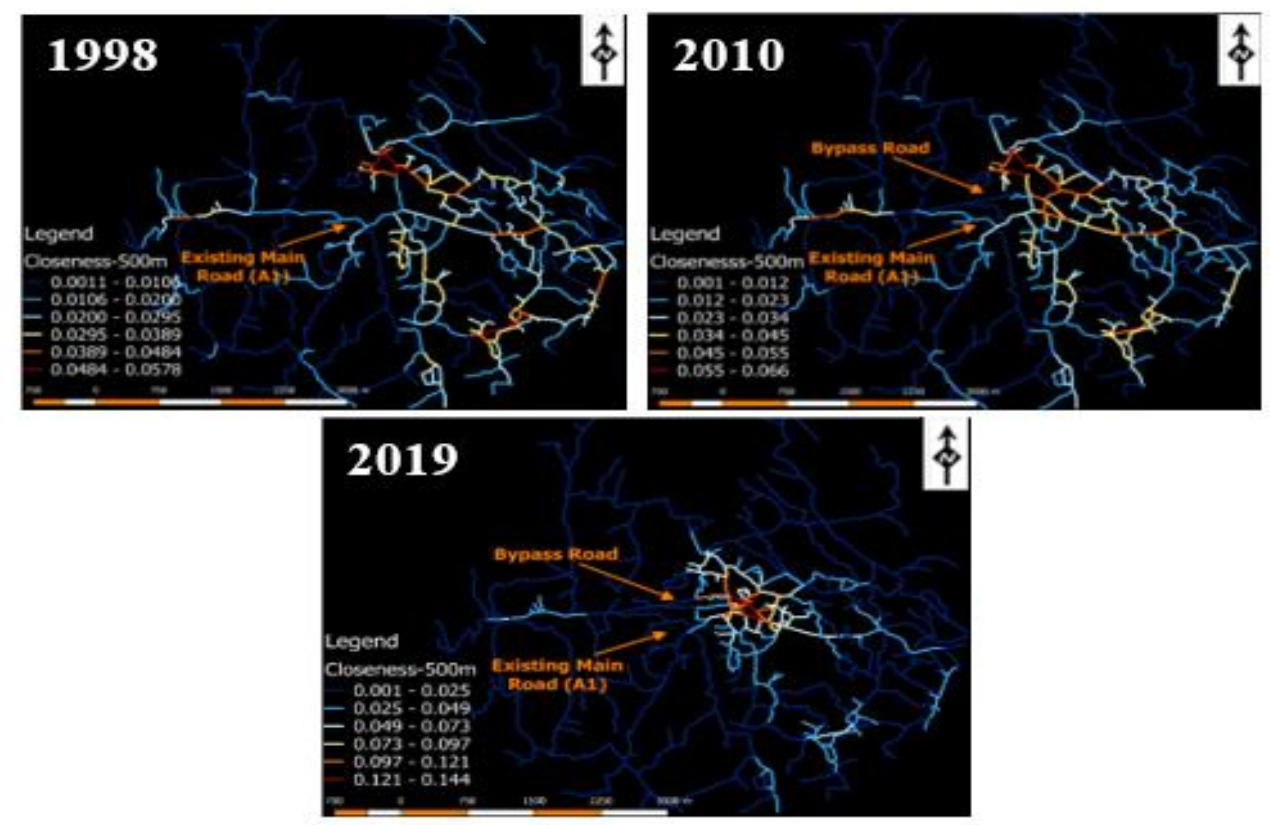

Figure 9: Variation of Closeness 500m values in road network of Mawanella town before and after bypass road construction 
Figure 10 below presents the variation of Closeness-n values in road network of Mawanella town before and after the construction of the bypass road.
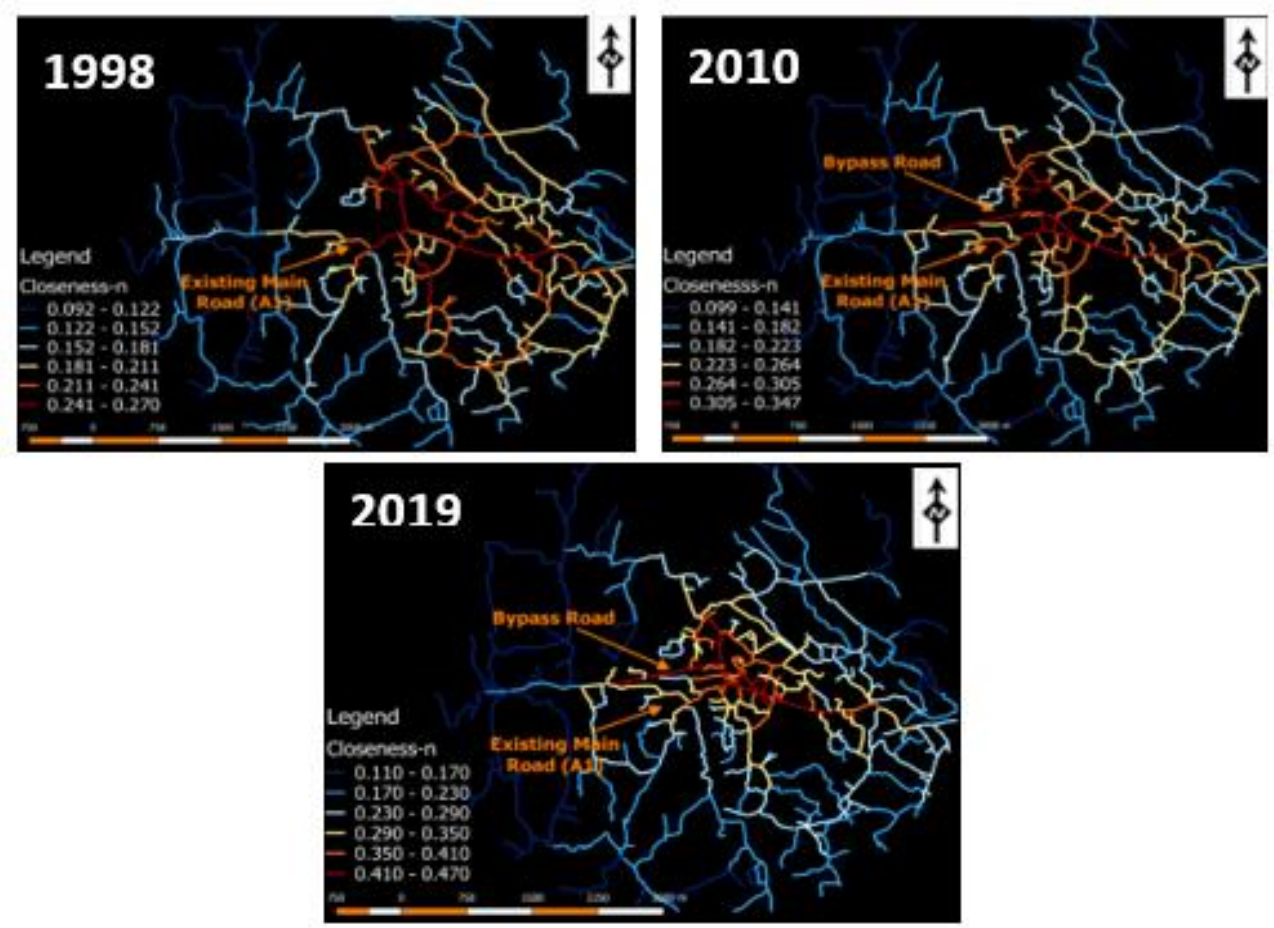

Figure: 10 Variation of Closeness-n values in road network of Mawanella town before and after bypass road construction.

As depicted in Figure 10, the CC-n values for both roads have increased gradually over the last two decades. However, the bypass road records a higher CC$n$ value when compared to the existing road. It indicates that the existing road has less potential to attract O-D trips, compared to the bypass road.

In the reference map series, changes of $\mathrm{BC}$ and $\mathrm{CC}$ are visible through the six colour ranges in the maps. The highest $\mathrm{BC}$ and $\mathrm{CC}$ values are shown in red and the lowest values are shown in blue. Accordingly, the use of colour range (red to blue) or values mentioned in legend help to identify $\mathrm{BC}$ and $\mathrm{CC}$ changes along the bypass and the existing road.

Figure 11 depicts the changes in building density in Mawanella from 1999 to 2019 with floor area ratio maps. New buildings have gradually appeared along with the construction of the new bypass road. However, building density along the bypass road $(F A R=0.8)$ remains higher than the building density along the existing road $(\mathrm{FAR}=0.72)$. 

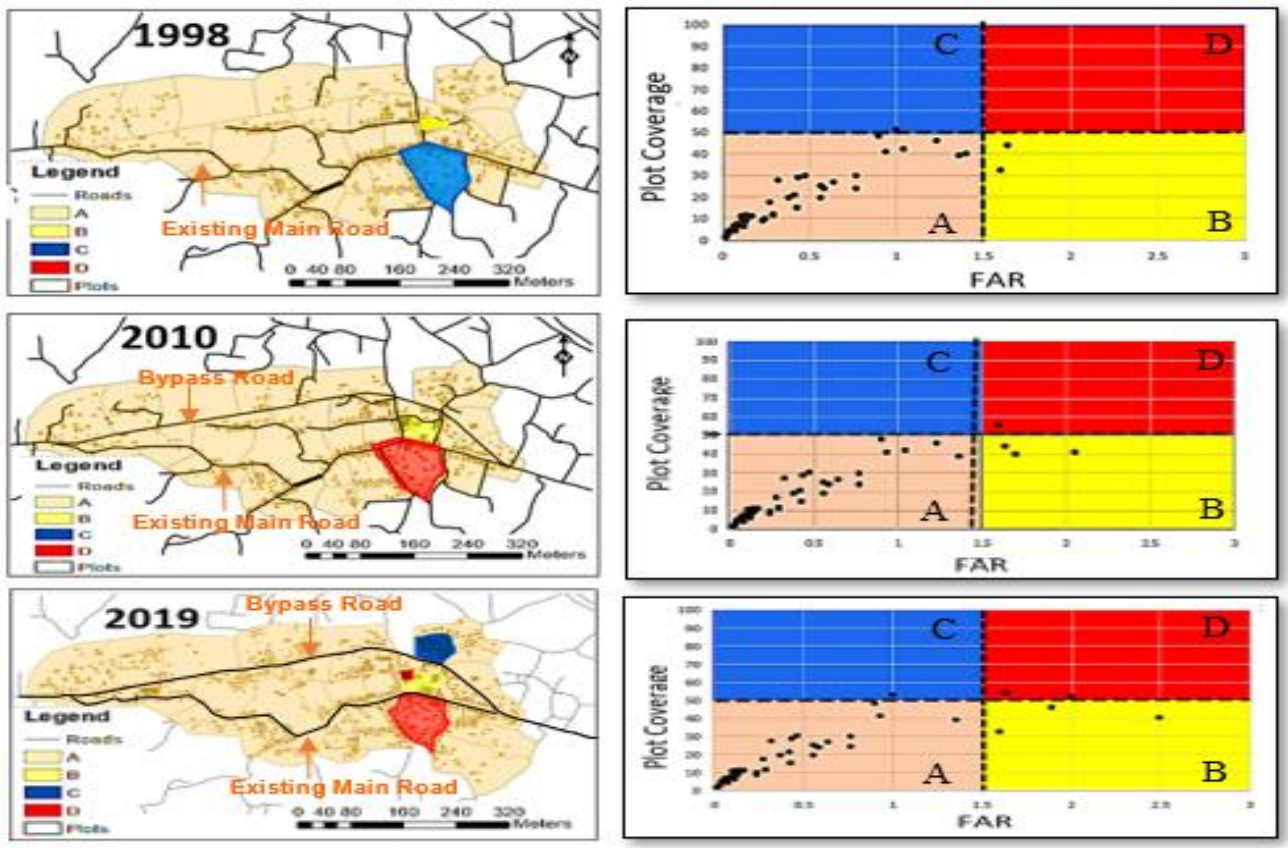

Figure 11: Variation of FAR values in building density of Mawanella town before and after bypass road construction

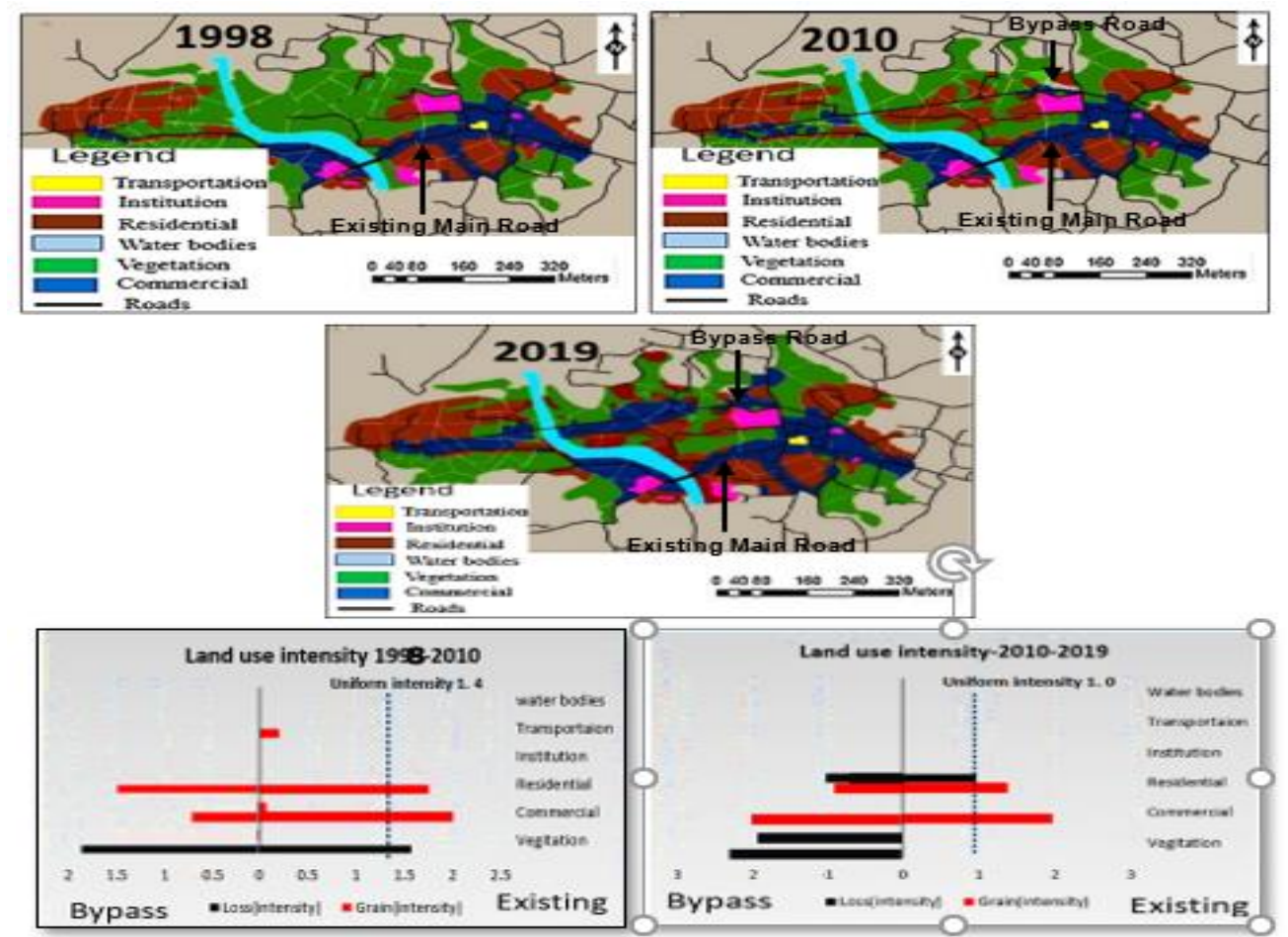

Figure 12: Variation of land use intensity values in land use of Mawanella town before and after bypass road construction 
Figure 12 depicts the results of the land use intensity analysis. As per the results, there was slow growth in commercial land use along the existing road during the period of 1999 to 2010 (after bypass roads). In early stages (1999-2010), the bypass road was able to attract residential land uses and gradually the bypass road was also able to attract a fast growth of commercial enterprises during the period of $2010-2019$.

Table 4: Summary of changes in Mawanella town area

\begin{tabular}{|c|c|c|c|c|}
\hline \multirow[t]{2}{*}{ Parameters } & \multirow{2}{*}{$\begin{array}{c}\text { Existing/ } \\
\text { Bypass }\end{array}$} & \multicolumn{3}{|c|}{ Years } \\
\hline & & 1999 & 2010 & 2019 \\
\hline \multirow[t]{2}{*}{ Building density } & Existing & 0.583 & 0.52 & 0.72 \\
\hline & Bypass & - & 0.63 & 0.8 \\
\hline \multirow[t]{2}{*}{ Betweenness n } & Existing & 69183 & 11305 & 10505 \\
\hline & Bypass & - & 10517 & 13491 \\
\hline \multirow[t]{2}{*}{ Closeness 500m } & Existing & 0.1228 & 0.0267 & 0.0746 \\
\hline & Bypass & - & 0.0345 & 0.0913 \\
\hline \multirow[t]{2}{*}{ closeness $n$} & Existing & 0.24 & 0.314 & 0.365 \\
\hline & Bypass & - & 0.314 & 0.4135 \\
\hline \multirow[t]{2}{*}{ Land use type } & Existing & 1 & 1 & 1 \\
\hline & Bypass & & 2 & 1 \\
\hline \multirow[t]{2}{*}{ Land use mix } & Existing & - & $\begin{array}{c}1=(+2.4),(-0.3) \\
2=(+1.8) \\
3=(-1.7) \\
5=(+0.4)\end{array}$ & $\begin{array}{c}1=(+1.8) \\
2=(+1.5),(-1) \\
3=(-1.8)\end{array}$ \\
\hline & Bypass & - & $\begin{array}{l}1=(+0.6) \\
2=(+1.5) \\
3=(-1.7)\end{array}$ & $\begin{array}{c}1=(+2.5) \\
2=(+0.8),(-0.9) \\
3=(-2.5)\end{array}$ \\
\hline
\end{tabular}

$* 1=$ Commercial, $2=$ Residential, $3=$ Vegetation, 4=Institution, 5= Transportation $*_{+}=$Grain intensity, - = Loss intensity

The changes in the Mawanella case study area due to the bypass road can be summarised as follows: with higher BC values, the bypass road was able to attract more pass-by trips than the existing road. The analysis of the previous section indicates that the accessibility (CC values) has increased in both roads. Accordingly, land use along both roads has gradually changed. However, the bypass road was able to attract commercial land use and high density, compared to the existing road. Furthermore, the bypass road was converted into the main centre of the town. The Mawanella town centre is located below $215 \mathrm{~m}$ elevation and the bypass road elevation does not exceed $215 \mathrm{~m}$. There is vegetation along the bypass road (refer Figure 13). 


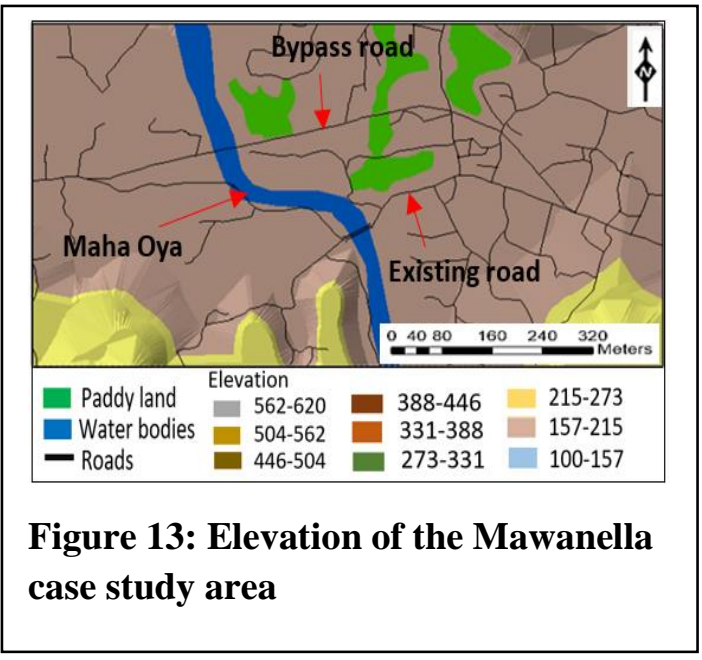

\begin{tabular}{c} 
Table 5: Existing Level of \\
service in both bypass road \\
and existing road in \\
Mawanella case study area \\
revel of Service- \\
Mawanella : 2019 \\
\hline $\begin{array}{cc}\text { Lypass } & \text { Existing } \\
\text { Road } & \text { Road } \\
\text { E (1.03) } & \text { C }(0.75)\end{array}$
\end{tabular}

Source: Compiled by author

Due to this, there is enough space to grow along the bypass road a factor that attracts new activities. Moreover, the location of the Old brick bridge and Maha Oya create a barrier to expand activities along the existing road and it helps to attract new investment to the bypass road. The case study results indicate that natural movement economic process has taken place owing to the available space for growth along the bypass road. Table 5 show existing traffic flow data on both of existing and bypass roads and it obviously confirmations both of bypass road and existing road have low level of service and not achieved the aim of the bypass road construction.

\subsubsection{Balangoda}

Balangoda is a small town (population $=81,563$ ) situated on the A4 route from Colombo to Batticaloa. The bypass road in Balangoda was constructed in 2006. Figures 14,15 and 16 illustrate the variations of accessibility in road network of Avissawella town over three different time periods: 2004, 2010, 2019. The level of accessibility is computed based on closeness (CC) and betweenness (BC) centrality parameters. BC-n values of the road network has been dramatically changing over the last decade after the construction of the bypass road. As depicted in Figure 14, the main road has been attracting higher BC values than the bypass road. It indicates that the existing road has more potential to capture pass by trips than the bypass road. As depicted in Figure 15, CC-500m values have gradually increased and the CC-500m values have been quite similar in both roads over the last decade. It indicates that, both roads have a similar level of potential to attract vehicle movements. Furthermore, there are very few connections between the bypass road and the existing road. It indicates that the bypass road has less potential to attract pedestrian movement compared to the existing road. 

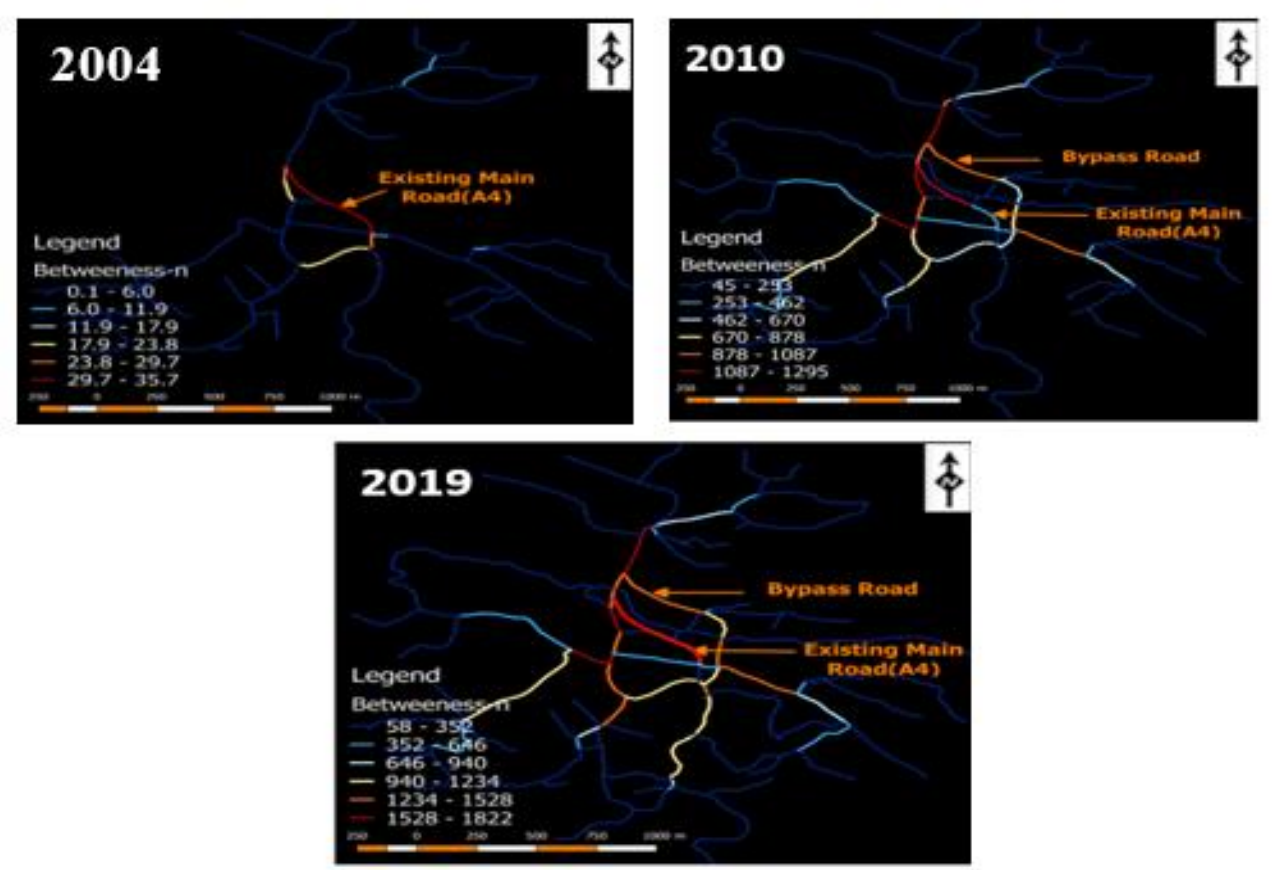

Figure 14: Variation of betweenness values in road network of Balangoda town before and after bypass road construction
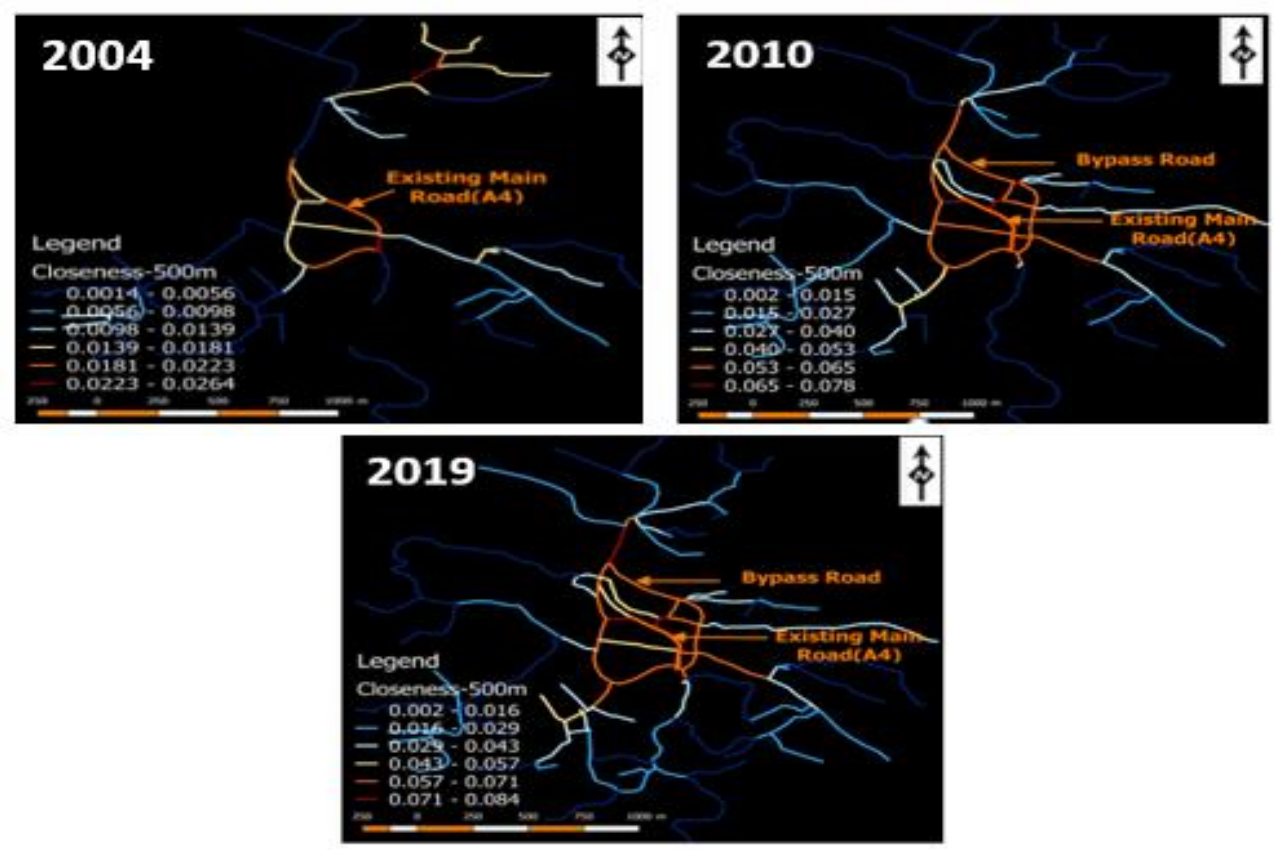

Figure 15: Variation of closeness-500m values in road network of Balangoda town before and after bypass road construction. 

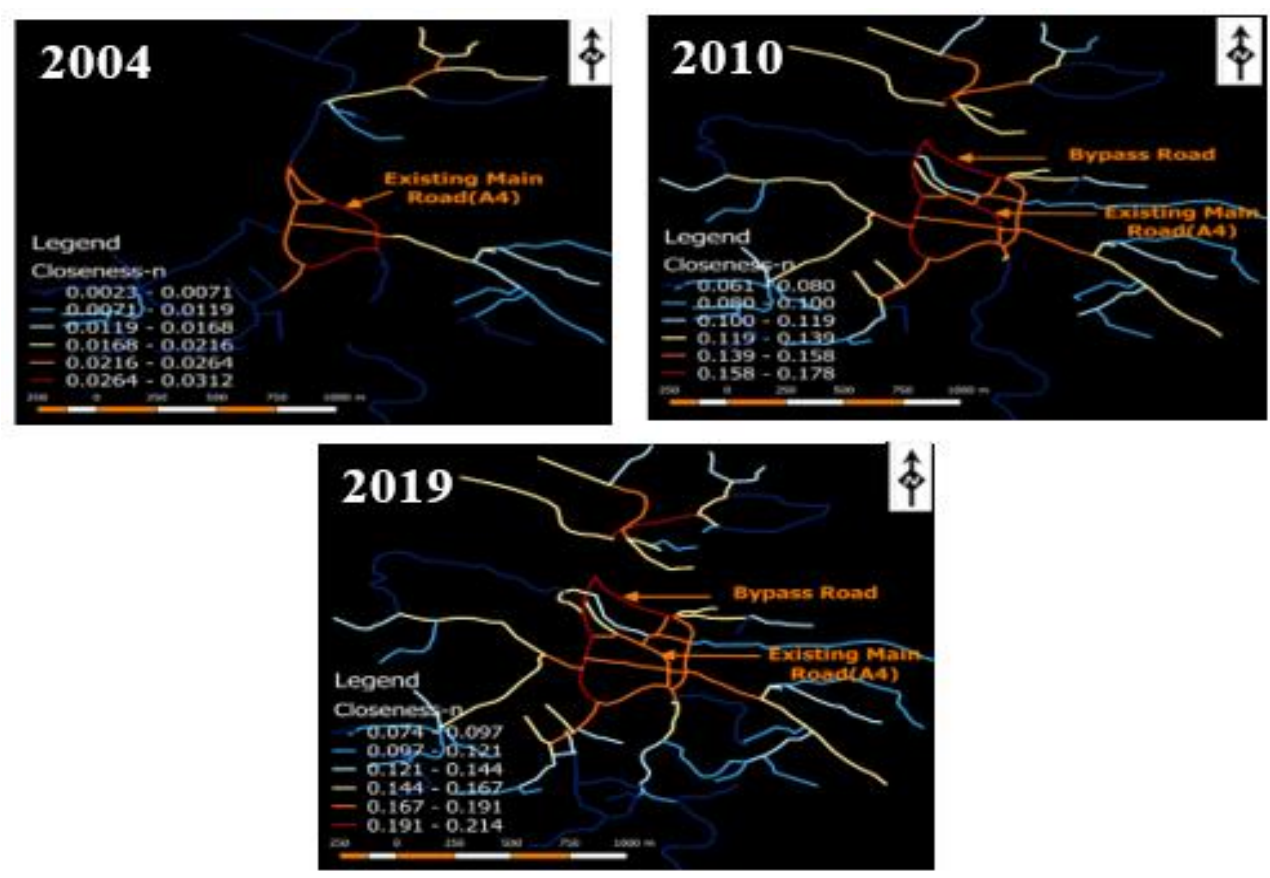

Figure 16: Variation of closeness-n values in road network of Balangoda town before and after bypass road construction.

As depicted in Figure 16, CC-n values have gradually increased in both roads over the last decade. However, the bypass road records a higher CC-n value compared to the existing road, it indicating that the existing road has less potential to attract $\mathrm{O}-\mathrm{D}$ trips movements comparatively. (In the reference map series, changes in value of $\mathrm{BC}$ and $\mathrm{CC}$ are visible through the six colour ranges in the maps. The highest $\mathrm{BC}$ and $\mathrm{CC}$ values are shown in red and the lowest values are shown in blue. Accordingly, the use of colour range (red to blue) or values mentioned in legend help to identify $\mathrm{BC}$ and $\mathrm{CC}$ changes along the bypass and the existing road.)

Figure 17 depicts the changes in building density in Balangoda from 2005 to 2019 with floor area ratio maps. New buildings have gradually appeared, with the construction of the new bypass road. However, building density along the existing main road $(F A R=1)$ remain higher than the building density along the bypass road $(\mathrm{FAR}=0.83)$. Figure 18 depicts the results of land use intensity analysis. As per the results, there was significant growth in commercial land use along the existing road during the period of 2005 to 2011 (after bypass roads). Moreover, many residential land uses have been converted into commercial operations along the existing road. Gradually, the bypass road was also able to attract residential land use during the period $2011-2019$. 

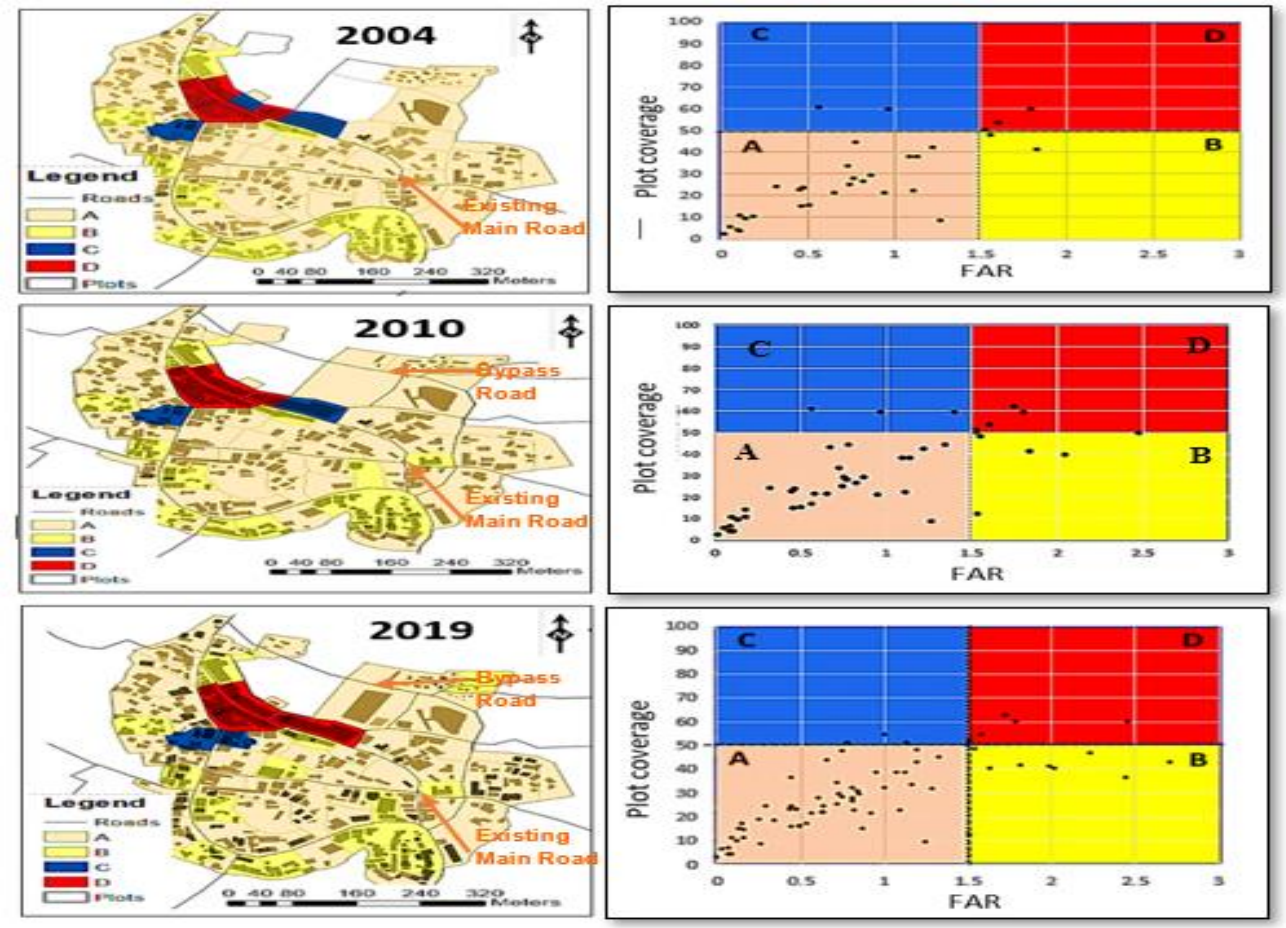

Figure 17: Variation of FAR values in building density of Balangoda town before and after bypass road construction
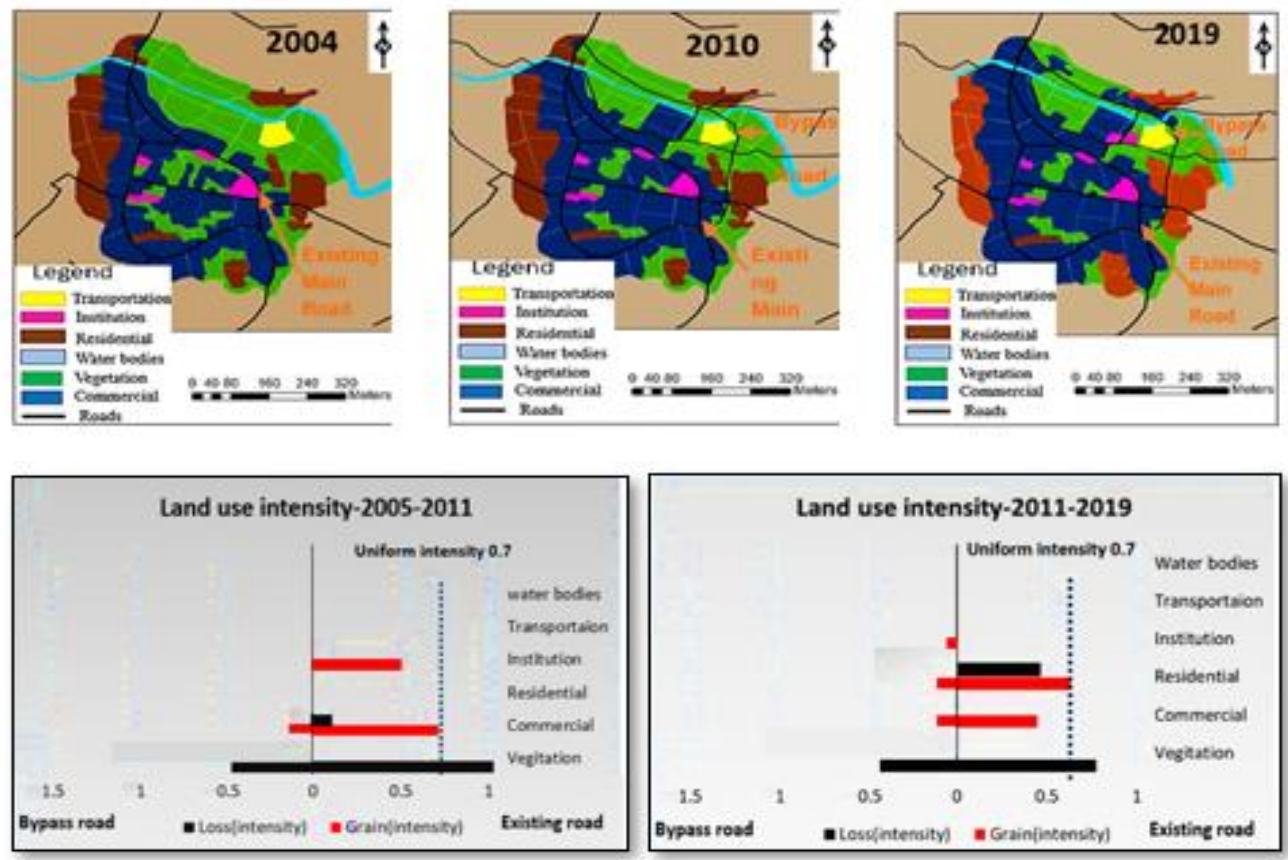

Figure 18: Variation of land use intensity values in land use of Balangoda town before and after bypass road construction. 
Table 6: Summary of changes in Balangoda town area.

\begin{tabular}{|c|c|c|c|c|}
\hline \multirow{2}{*}{ Parameters } & \multirow{2}{*}{$\begin{array}{c}\text { Existing/ } \\
\text { Bypass }\end{array}$} & \multicolumn{3}{|c|}{ Years } \\
\hline & & 2005 & 2011 & 2019 \\
\hline \multirow{2}{*}{ Building density } & Existing & 1.3 & 1.36 & 1 \\
\hline & Bypass & - & 0.73 & 0.83 \\
\hline \multirow{2}{*}{ Betweenness n } & Existing & 10.56 & 894 & 1428 \\
\hline & Bypass & - & 658 & 1157 \\
\hline \multirow{2}{*}{ Closeness 500m } & Existing & 0.0182 & 0.0571 & 0.064 \\
\hline & Bypass & - & 0.0905 & 0.064 \\
\hline \multirow{2}{*}{ closeness $n$} & Existing & 0.123 & 0.159 & 0.132 \\
\hline & Bypass & - & 0.154 & 0.184 \\
\hline \multirow{2}{*}{ Land use type } & Existing & 1 & 1 & 1 \\
\hline & Bypass & - & 3 & 2 \\
\hline \multirow[b]{2}{*}{ Land use mix } & Existing & - & $\begin{array}{c}1=(+0.7),(-0.2) \\
3=(-1.2) \\
4=(+0.5)\end{array}$ & $\begin{array}{c}1=(+0.4) \\
2=(+0.7),(-0.5) \\
3=(-0.8)\end{array}$ \\
\hline & Bypass & - & $\begin{array}{l}1=(+0.2) \\
3=(-0.4)\end{array}$ & $\begin{array}{c}1=(+0.1) \\
2=(+0.1) \\
3=(-0.4) \\
4=(+0.05)\end{array}$ \\
\hline
\end{tabular}

$* 1=$ Commercial, $2=$ Residential, $3=$ Vegetation, 4=Institution, 5= Transportation $*_{+}=$Grain intensity, - = Loss intensity

The changes of the Balangoda case study area due to the bypass road can be summarised as follows: With higher $\mathrm{BC}$ values, the existing road has been able to attract more pass by trips than the bypass road. The analysis result of the previous section indicates that the CC-500m values have increased in both roads, but the bypass road records a higher CC-n value when compared to the existing road. Accordingly, land use along both roads have changed gradually. However, the bypass road has been unable to attract commercial land uses and high density compared to the existing road. Furthermore, the existing main road remains as the main centre of the town. The Balangoda town centre is located below $350 \mathrm{~m}$ elevation, and close to the bypass road, the elevation goes up to more than $560 \mathrm{~m}$. There is a mountain along the bypass road (refer Figure. 19). Dorawale Oya flows near the bypass road and there is a playground and a Pola area to the left side of this road. These factors obstruct the space to grow and act as a barrier to attract new activities along the bypass road. The case study results indicate that natural movement economic process is disturbed due to lack of space for growth along the bypass road. Table 7 show existing traffic flow data on both of existing and bypass roads and it confirms that the bypass road has a high level of service relative to the existing road. 


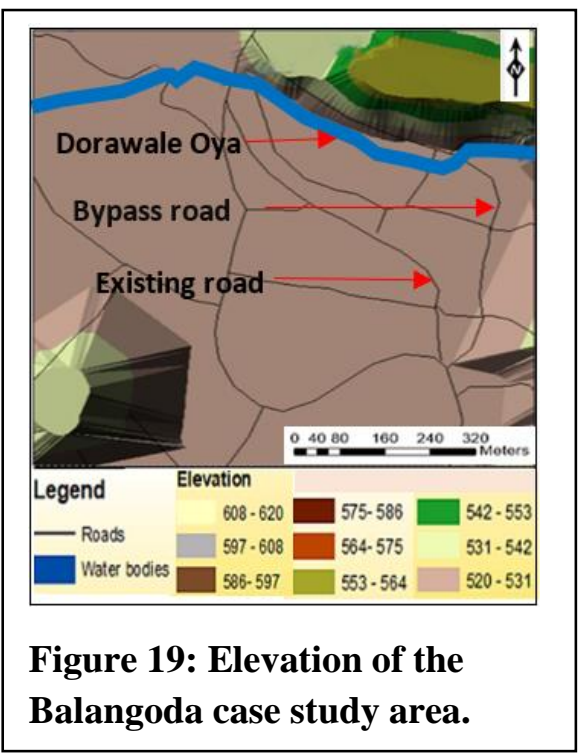

\section{Table 7: Existing Level of service in both bypass road and existing road in Balangoda case study area}

Level of Service - Balangoda: 2019

\begin{tabular}{cc}
$\begin{array}{c}\text { Bypass } \\
\text { Road }\end{array}$ & Existing Road \\
E $(0.11)$ & $\mathrm{C}(0.46)$ \\
\hline
\end{tabular}

Source: Compiled by author

\subsubsection{Piliyandala}

Piliyandala is a small town (population $=185,22$ ) situated on the B84 route from Colombo to Horana. The bypass road in Piliyandala was constructed in the year 2014. Figures 20, 21 and 22 illustrate the variations of accessibility in the road network of Piliyandala town in 2011 and 2019. The level of accessibility is computed based on the closeness (CC) and betweenness (BC) centrality parameters. BC-n values of the road network has been dramatically changing over the last five years after the construction of the bypass road. As depicted in Figure 20, the prominence of the main road has reduced while the bypass road attracts higher BC values. It indicates that the bypass road has more potential to capture pass-by trips than the existing road.
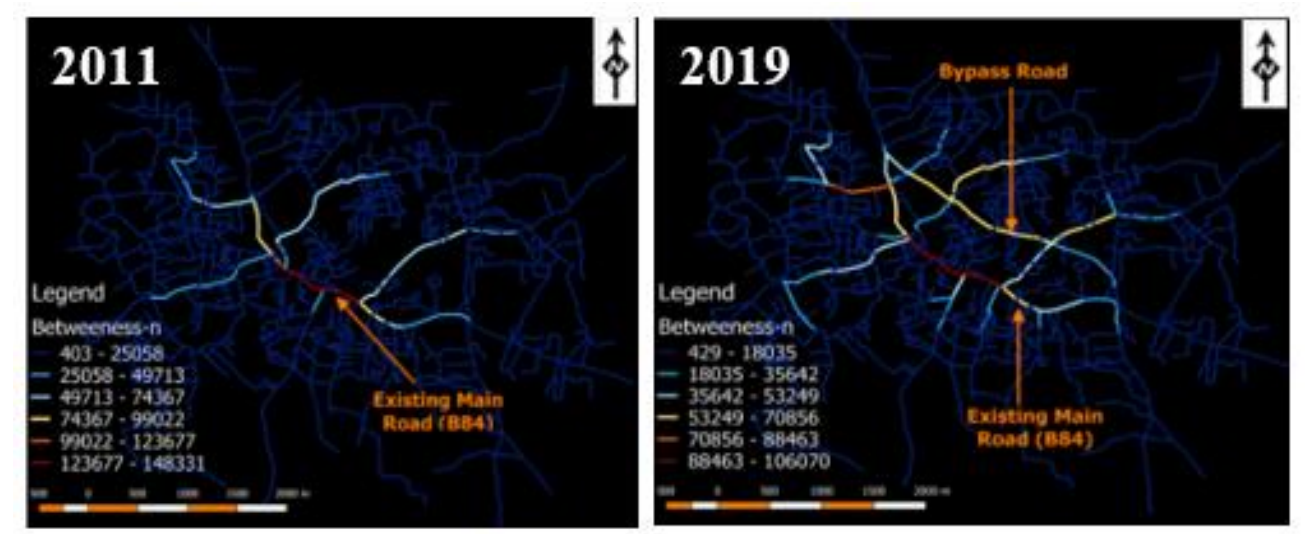

Figure 20: Variation of betweenness values in road network of Piliyandala town before and after bypass road construction 

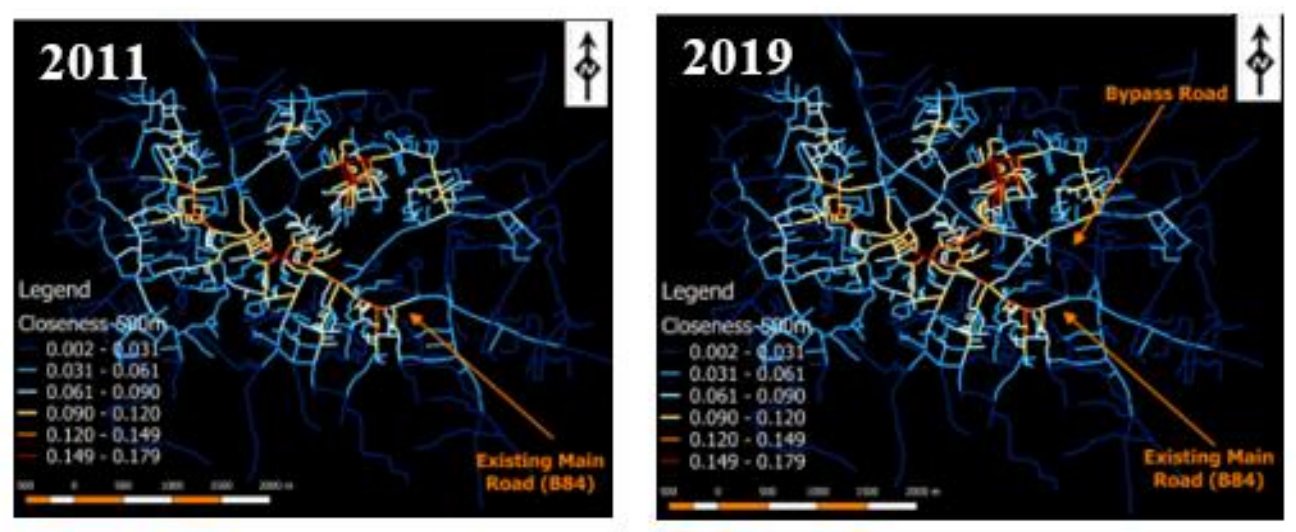

Figure 21: Variation of closeness-500m values in road network of Piliyandala town before and after bypass road construction.

As depicted in Figure 21, CC-500m values have increased in existing roads and the CC-n values have been quite similar in both roads over the last seven years. It indicates that both roads have a similar level of potential to attract vehicle movements. (in the reference map series, changes in value of $\mathrm{BC}$ and $\mathrm{CC}$ are visible through the six colour ranges in the maps. The highest $\mathrm{BC}$ and $\mathrm{CC}$ values are shown in red and the lowest values are shown in blue. Accordingly, the use of colour range (red to blue) or values mentioned in legend help to identify $\mathrm{BC}$ and $\mathrm{CC}$ changes along the bypass and the existing road.)
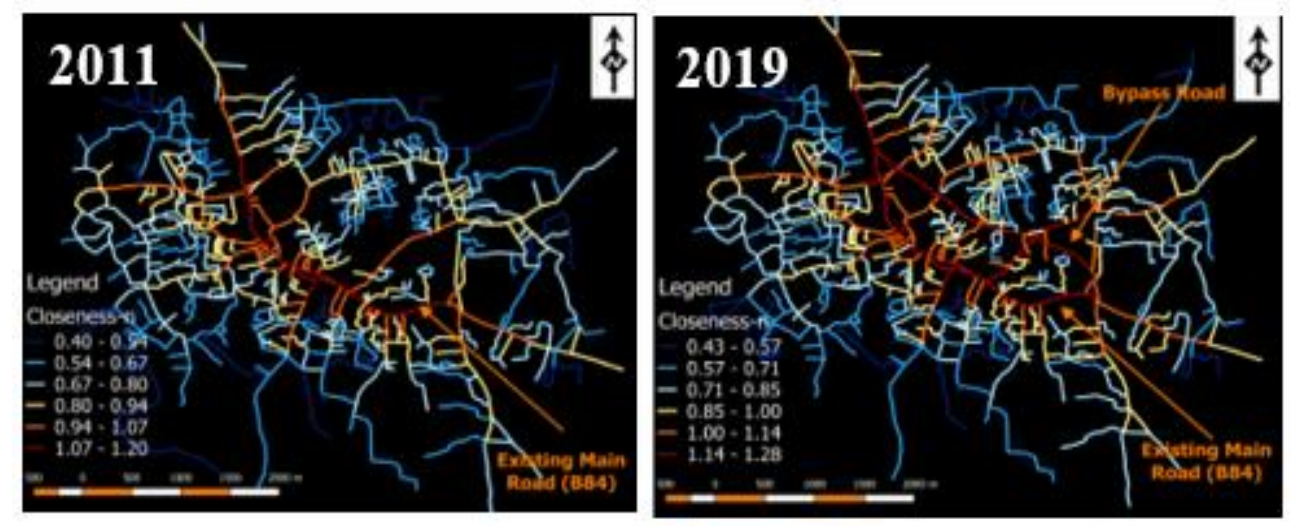

Figure 22: Variation of closeness-n values in road network of Piliyandala town before and after bypass road construction

Figure 23 depicts the changes in building density in Piliyandala from 2011 to 2019 with floor area ratio maps. New buildings have gradually appeared on the bypass road with the construction of the new bypass road. However, building density along the existing main road $(\mathrm{FAR}=2)$ remains higher than the building density along the bypass road $(\mathrm{FAR}=0.6)$. 

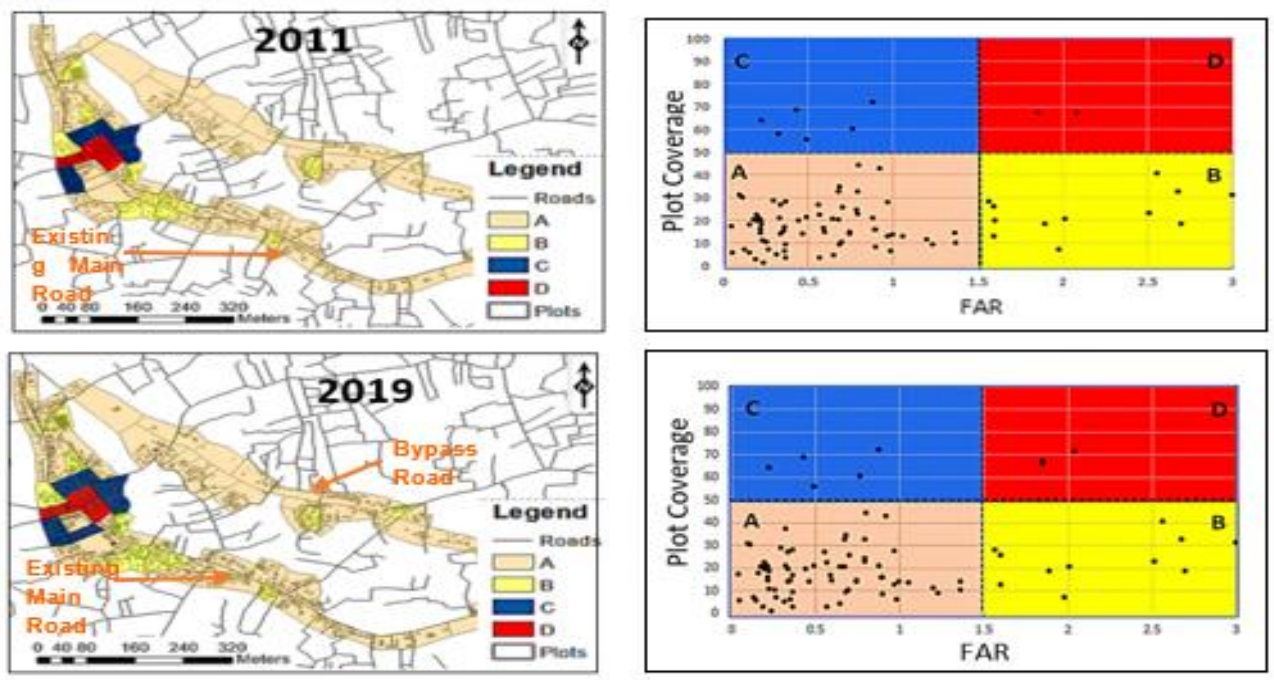

Figure 23: Variation of FAR values in building density of Piliyandala town before and after bypass road construction.

Figure 24 depicts the results of the land use intensity analysis. As per the results, there has been significant growth in commercial land uses along the existing road after the bypass road implementation (2019). Furthermore, many residential land uses have been converted into commercial activities along the existing road. However, there has not been a significant growth of varying types of land uses along the bypass road after the bypass implementation.
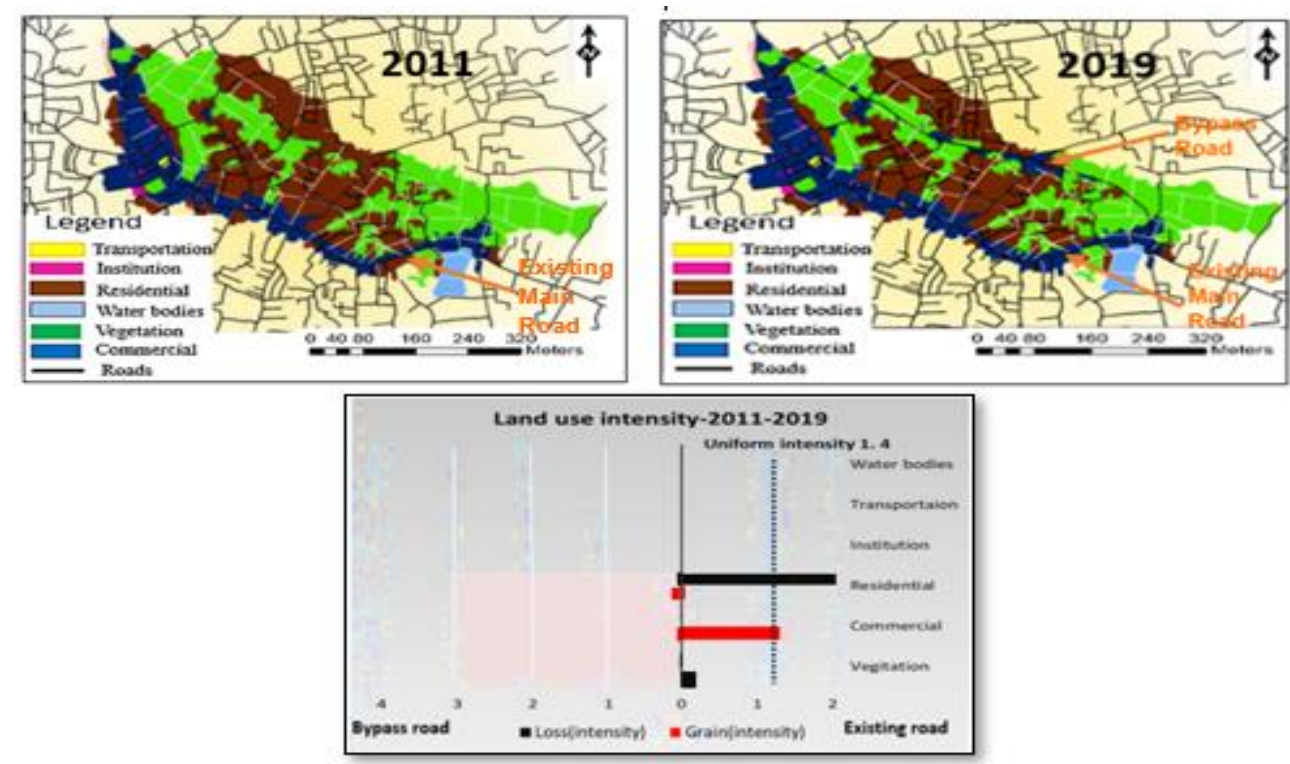

Figure 24: Variation of land use intensity values in land use of Piliyandala town before and after bypass road construction. 
Table 8 summarised the above mentioned changes in Piliyandala town area.

\begin{tabular}{|c|c|c|c|}
\hline \multirow{2}{*}{ Parameters } & & \multicolumn{2}{|c|}{ Years } \\
\hline & & 2005 & 2019 \\
\hline \multirow{2}{*}{ Building density } & Existing & 2 & 2 \\
\hline & Bypass & - & 0.6 \\
\hline \multirow{2}{*}{ Betweenness $n$} & Existing & 81117 & 66775 \\
\hline & Bypass & - & 83644 \\
\hline \multirow{2}{*}{ Closeness 500m } & Existing & 0.0598 & 0.0656 \\
\hline & Bypass & - & 0.0543 \\
\hline \multirow{2}{*}{ closeness n } & Existing & 0.68 & 1.2 \\
\hline & Bypass & - & 1.2 \\
\hline \multirow{2}{*}{ Land use type } & Existing & 2 & 1 \\
\hline & Bypass & - & 3 \\
\hline \multirow{2}{*}{ Land use mix } & Existing & - & $\begin{aligned} & 1=(+1.5) \\
2= & (+0.01),(-2) \\
& 3=(-0.2)\end{aligned}$ \\
\hline & Bypass & - & $\begin{array}{c}1=(+0.01) \\
2=(+0.25),(-0.0) \\
3=(-0.012)\end{array}$ \\
\hline
\end{tabular}

$* 1=$ Commercial, 2= Residential, 3= Vegetation, 4=Institution, 5= Transportation $*_{+}=$Grain intensity, - = Loss intensity

The changes of the Piliyandala case study area due to the bypass road can be summarised as follows: With higher BC values the bypass road has been able to attract more pass-by trips than the existing road. The analysis of the previous section indicates that the CC-n values have increased in both roads, but higher CC-500m values have increased in the existing road than the bypass road. Accordingly, land use along both roads has altered gradually. However, the bypass road has been unable to attract significant land uses and high density, when compared with the existing road. Furthermore, the existing main road remains the main centre of the town. According to rules and regulation introduced, no building can be constructed within $15 \mathrm{~m}$ along the Piliyandala bypass road or get direct access from the bypass road to buildings or street vendors' activities etc. The abandoned paddy land along the bypass road has been identified as a wetland protection zone, resulting in lack of space to grow along the bypass road. This acts as a barrier to attract new activities. The case study results indicate that natural movement economic process is disturbed owing to the lack of space for growth along the bypass road. Table 9 shows existing traffic flow data on both of existing and bypass roads. It confirms that the bypass road has a high and good level of service relative to the existing road. 
Table 9: Level of service in both bypass road and existing road in Piliyandala case study area

\begin{tabular}{|c|c|}
\hline \multicolumn{2}{|c|}{ Level of Service-Piliyandala - 2019} \\
\hline Bypass Road & Existing Road \\
\hline A $(0.17)$ & B $(0.54)$ \\
\hline
\end{tabular}

Source: Compiled by author

\section{CONCLUSION}

Limited studies have been carried out in Sri Lanka to study the impact of bypass roads in towns where the main transport route is replaced by another outside the town. This study explores the effects of a bypass road on build form of a town. The study investigates the changes in land use and building density along with accessibility changes and analysed the before and after situation for bypass roads in four small towns in Sri Lanka. The study analysed the temporal changes using spatial analysis tools in a GIS environment; and used three parameters as land use intensity, building density and accessibility to capture temporal changes in selected case town areas. Only four cases were studied, and the study was predominantly based on available secondary data. Analysis focused only on accessibility, land use and density parameters. The study recommends incorporating analysis related to temporal changes in traffic characteristics such as traffic volume -AADT, speed and the road characteristics such as number of lanes, carriageway dimensions of the existing and bypass road in future studies.

The results of the above case studies indicate three scenarios: i) Bypass road accessibility improves more than the existing main road and new land uses and highdensity areas emerge along the by-pass road, and the bypass road becomes the main centre of the town; ii) The bypass road and the existing main road show similar levels of accessibility and attraction; and iii) Accessibility of the existing main road remains higher than the bypass road and very few new lands uses and built-up area is attracted towards the bypass road ensuing that the existing main road continues as the main centre of the town. The results indicate that if accessibility to the new bypass is higher than to the existing main road, the commercial activities and buildings move towards the bypass road. However, if accessibility does not change in the town after the introduction of the new bypass road, the commercial activities and buildings do not move. The results confirm that spatial and economic forces are closely interrelated as indicated in the theory of the natural movement economic process. However, the study found out that certain forces such as mountains, paddy fields etc. which are 
natural barriers constrain the space to grow. Accordingly, the study suggests that the findings of this study is useful for transport engineers in making new strategies to implement bypass roads as well as for urban planners to develop local development plans after constructing bypass roads.

\section{REFERENCES}

[1] Munasinghe, J. (2012). Self Organization \& Planning: The Case of Small Towns in Sri Lanka, International Congress on Emerging Urban Planning Trends in Asia. In J. Munasinghe, Transforming Asian cities (pp. 1-15).

[2] Sander, L., Karine, 1., \& Akkelies, V. (2019). The effects of new bypass road on small Norwegian towns. Research gate, 1-17.

[3] Florida Department of Transportation. (2010). Impacts of Bypass Highways on Small and Medium Size Cities in Florida:. Florida: Center for Urban Transportation Research, University of South Florida.

[4] Falleth, E. I., Kolbton, K., \& Tombre, E. (1995). Arealutvikling langs omkjøringsveier - En undersøkelse av arealbruksendringer og fysisk planlegging.

[5] Van Nes, A. (2002). Road building and urban change.

[6] Van Nes, A., \& Stolk, E. (2012). The socioeconomic impact of various road alternatives in town centres - The application of space syntax in road planning in Rijnland and Tønsberg. Paper presented at the AESOP conference.

[7] Jayasinghe, A., \& Munasinghe, J. (2013〉). A study of the urbanizing pattern in Kegalle district, Sri Lanka with connectivity analysis. International Journal, 2(1), 2305-1493.

[8] Hillier, B. (1996). Cities as movement economics. Cambridge University Press, 41-48.

[9] Perera, N. (2015). People's space: Coping, Familiarizing, Creating (1st edition). New York, NY: Routledge.

[10] Xiao, S., Qiaozhen, G., Xiaoxu, W., Ying, F., Tongyao, X., Chengwei, H., \& Jinlong, Z. (2019). Intensity and Stationarity Analysis of Land Use Change Based on CART Algorithm. 9(1), 1-12. doi:10.1038/s41598-01948586-3

[11] Ann, F., \& Brennan, C. (2016). Revitalizing Places: Improving Housing and Neighborhoods from Block to Metropolis. Harvard, 233-237. 
[12] Van Nes, A., Mashoodi, B., \& pont, M. B. (2012). combination of space syntax with spacematrix and the mixed used index:The rotterdam South test case. Research gate, 1-30.

[13] Jayasinghe, A., Sano, K., Abenayake, C. C., \& \& Mahanama, P. K. (2019). A novel approach to model traffic on road segments of large-scale urban road networks. MethodsX, 6, 1147-1163.

[14] Porta, S., Latora, V., Wang, F., Rueda, S., Strano, E., Scellato, S., .. Latora, L. (2012). Street Centrality and the Location of Economic Activities in Barcelona. Urban Studies, 49(7), 1471-1488.

[15] Jayasinghe, A., Sathsarana, H., Rathnayake, R., \& Bandara, N. (2020). A Novel Method to Model Spatial Distribution of Population. International Journal of Innovative Technology and Exploring Engineering, 9(3S), 34-40.

[16] Sanjaya, N., A., J., \& P., J. (2014). Space Syntax And Mobile GIS Application: Investigation Of Relationship Between Human Walking Pattern And Spatial Configuration. International Journal of Emerging Technology \& Research, 1(6), 1-7.

[17] Chiaradia, A., Cooper, C., \& Webster, C. (2013). sDNA a software for spatial design network analysis. Cardiff: Cardiff University.

[18] Tenzin, N., Jayasinghe, A., \& Abenayake, C. (2019). Road Network Centrality based Model to Simulate Population Distribution. Journal of the Eastern Asia Society for Transportation Studies, 13, 1194-1215.

[19] Turner, A. (2001). Angular analysis. Proceedings of the 3rd international symposium on space syntax, (p. 30).

[20] Jayasinghe, A.; Madusanka, N.B.S.; Abenayake, C.; Mahanama, P.K.S. A Modeling Framework: To Analyze the Relationship between Accessibility, Land Use and Densities in Urban Areas. Sustainability 2021, 13, 467 


\section{APPENDICES}

Table - A1: Description about secondary data

\begin{tabular}{|c|c|c|}
\hline Data type & Year & Source \\
\hline \multirow[t]{4}{*}{ Land use } & 1989 & $\begin{array}{l}\text { Newspaper } \\
\text { The island newspaper under the heading of Rampala regime in } \\
\text { the local Railway History. Newspaper: } \\
\text { http://www.sundayobserver.lk/2017/08/29/spectrum/lost- } \\
\text { glory-kv-railway-line } \\
\text { Old maps } \\
\text { Avissawella land use maps (Collected from Seethawakapura } \\
\text { Urban Council) }\end{array}$ \\
\hline & 1992 & $\begin{array}{l}\text { Reports } \\
\text { Report of transport plan for Avissawella town development } \\
\text { project done by UDA } \\
\text { Old maps } \\
\text { Avissawella land use map (Collected from Seethawakapura } \\
\text { Urban Council) }\end{array}$ \\
\hline & 2007 & Google earth \\
\hline & 2019 & Google earth \\
\hline \multirow[t]{4}{*}{ Building } & 1989 & $\begin{array}{l}\text { Newspaper } \\
\text { The island newspaper under the heading of Rampala regime in } \\
\text { the local Railway History }\end{array}$ \\
\hline & 1992 & $\begin{array}{l}\text { Report } \\
\text { Report of transport plan for Avissawella town development } \\
\text { project done by UDA }\end{array}$ \\
\hline & 2007 & Google Earth, \\
\hline & 2019 & Google Earth, \\
\hline \multirow[t]{3}{*}{$\begin{array}{c}\text { Road } \\
\text { network }\end{array}$} & 2006 & $\begin{array}{l}\text { Newspaper } \\
\text { The island newspaper under the heading of Rampala regime in } \\
\text { the local Railway History. Newspaper: } \\
\text { http://www.sundayobserver.lk/2017/08/29/spectrum/lost- } \\
\text { glory-kv-railway-line } \\
\text { Old maps } \\
\text { Avissawella land use map (Collected from Seethawakapura } \\
\text { Urban Council) } \\
\text { Reports } \\
\text { Report of transport plan for Avissawella town development } \\
\text { project done by UDA }\end{array}$ \\
\hline & 2010 & Google Earth \\
\hline & 2019 & Google Earth \\
\hline
\end{tabular}

Source: Compiled by author 
Table- A2: Description about primary data

\begin{tabular}{|c|l|c|}
\hline Data type & \multicolumn{1}{|c|}{ Method of data collection } & Sample \\
\hline Land use & $\begin{array}{l}\text { Field observation= Observe the case study area and take } \\
\text { photographs, Observe the area and mark a map including } \\
\text { important data. }\end{array}$ & - \\
\cline { 2 - 3 } & $\begin{array}{l}\text { Informal discussion= Specially discuss with elderly people } \\
\text { and urban council officers and according to the collected data } \\
\text { maintain a map within the field. }\end{array}$ & 50 \\
\hline Building & $\begin{array}{l}\text { Field observation= Observe the case study area and take } \\
\text { photographs, Observe the area and mark a map including } \\
\text { important data }\end{array}$ & - \\
\cline { 2 - 4 } & $\begin{array}{l}\text { Informal discussion= Specially discuss with elderly people } \\
\text { and urban council officers and according to the collected data } \\
\text { maintain a map within the field. }\end{array}$ & 35 \\
\hline Road & $\begin{array}{l}\text { Field observation= Observe the case study area and take } \\
\text { photographs, Observe the area and mark a map including } \\
\text { important data. }\end{array}$ & - \\
\cline { 2 - 4 } & $\begin{array}{l}\text { Informal discussion= Specially discuss with elderly people } \\
\text { and urban council officers and according to the collected data } \\
\text { maintain a map within the field. }\end{array}$ & 20 \\
\hline
\end{tabular}

Source: Compiled by author

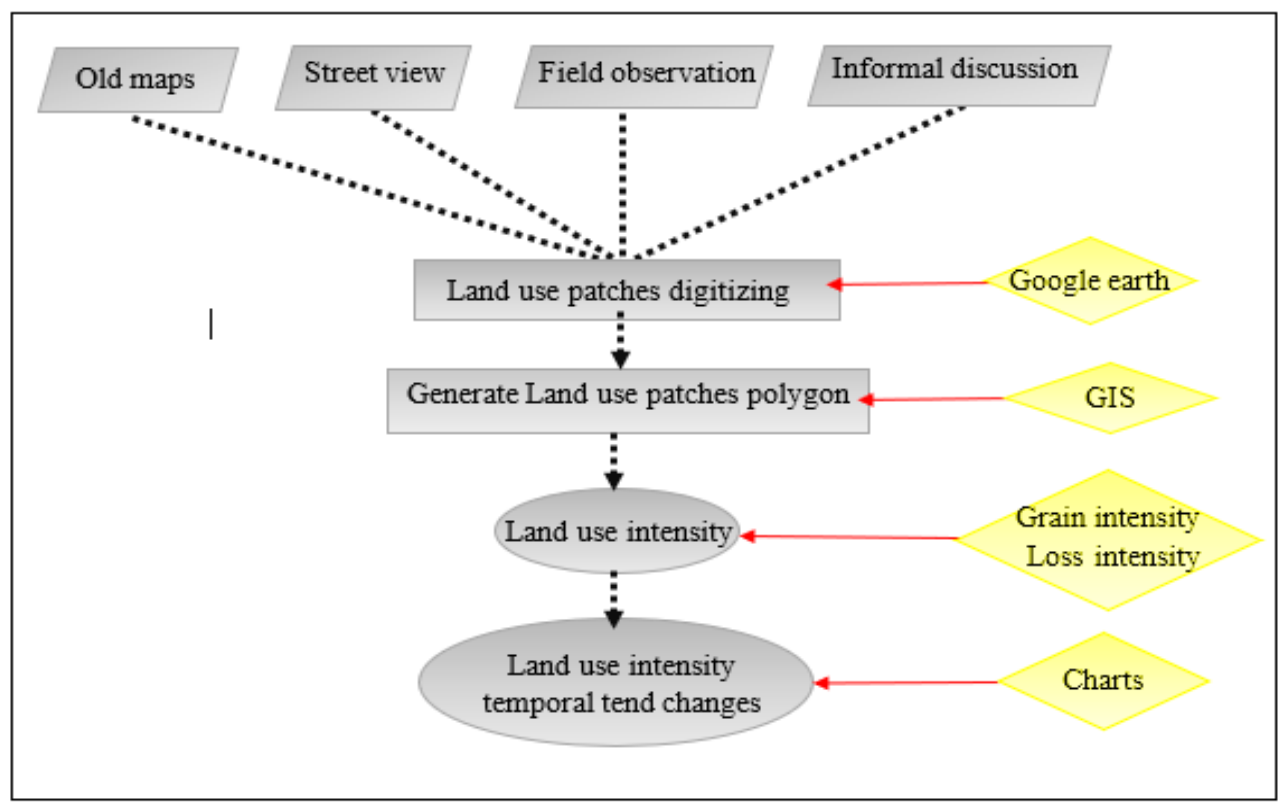

Source: Compiled by author

Figure- A1 Steps of land use intensity temporal trend changes analysis 


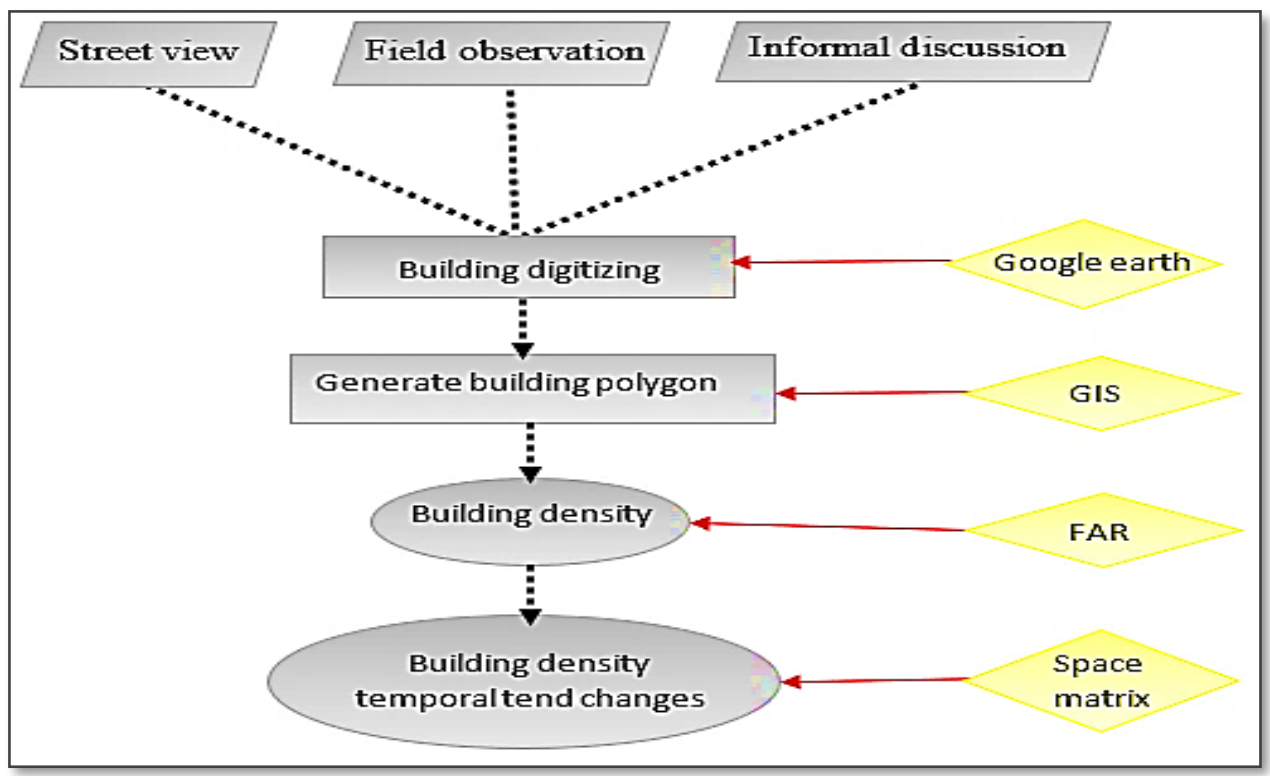

Source: Compiled by author

Figure -A2: Steps of building density temporal trend changes analysis

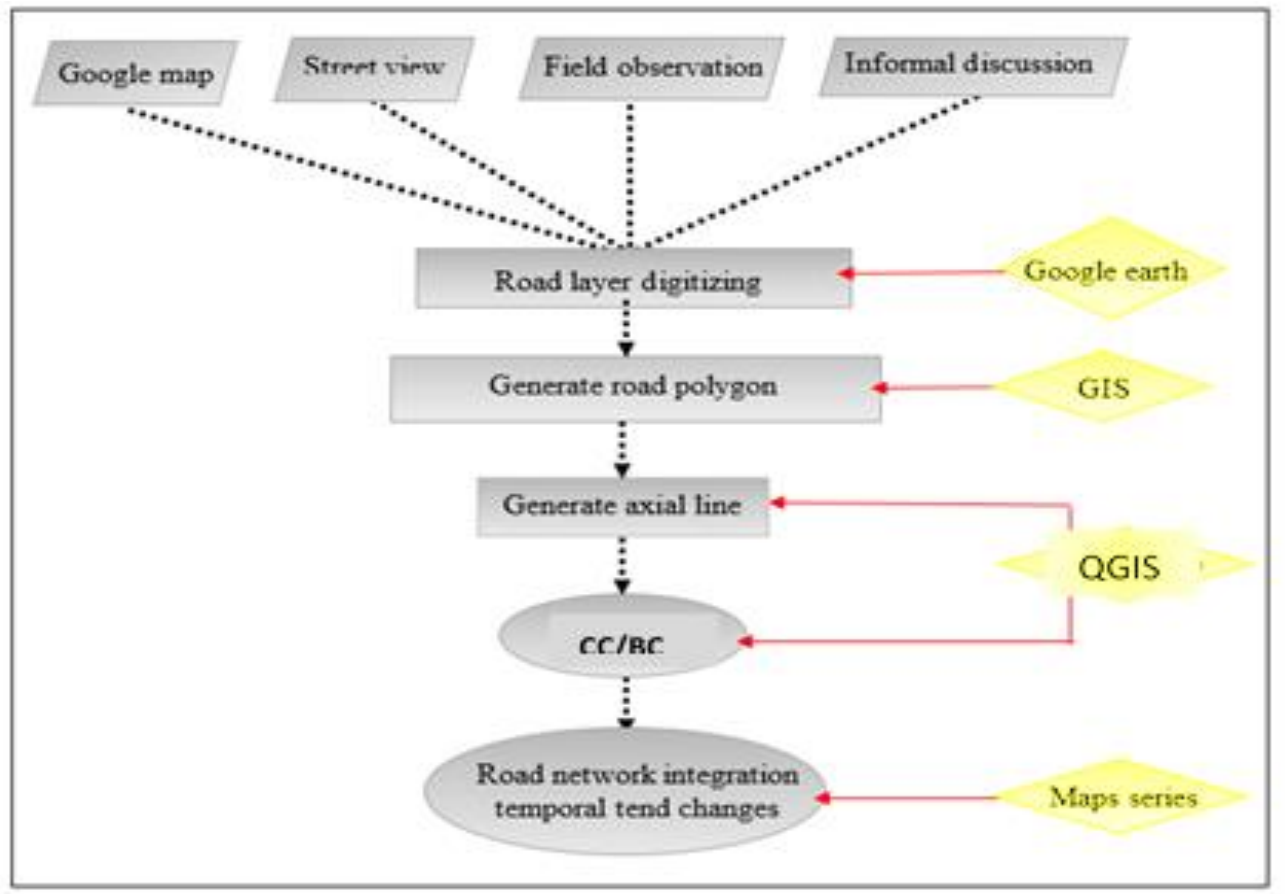

Source: Compiled by author

Figure -A3: Steps of accessibility temporal changes analysis 